\title{
Neuroimmune-Glia Interactions in the Sensory Ganglia Account for the Development of Acute Herpetic Neuralgia
}

\author{
Jaqueline R. Silva, ${ }^{1,2}$ Alexandre H. Lopes, ${ }^{1}$ Jhimmy Talbot, ${ }^{1}$ Nerry T. Cecilio, ${ }^{1}$ Mateus F. Rossato, ${ }^{1}$ @Rangel L. Silva, ${ }^{1}$ \\ Guilherme R. Souza, ${ }^{1}{ }^{\circ}$ Cassia R. Silva, ${ }^{1}$ Guilherme Lucas, ${ }^{3}$ Benedito A. Fonseca, ${ }^{4}{ }^{\circ}$ Eurico Arruda, ${ }^{5}$

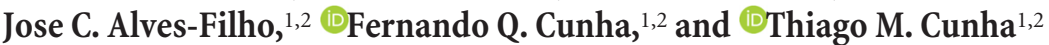 \\ ${ }^{1}$ Department of Pharmacology, ${ }^{2}$ Graduate Program in Basic and Applied Immunology, ${ }^{3}$ Department of Physiology, ${ }^{4}$ Department of Internal Medicine, and \\ ${ }^{5}$ Department of Cellular Biology, Ribeirão Preto Medical School, University of São Paulo, São Paulo 14040900, Brazil
}

Herpetic neuralgia is the most important symptom of herpes zoster disease, which is caused by Varicella zoster. Nevertheless, the pathophysiological mechanisms involved in herpetic neuralgia are not totally elucidated. Here, we examined the neuroimmune interactions at the sensory ganglia that account for the genesis of herpetic neuralgia using a murine model of Herpes Simplex Virus Type-1 (HSV-1) infection. The cutaneous HSV-1 infection of mice results in the development of a zosteriform-like skin lesion followed by a time-dependent increase in pain-like responses (mechanical allodynia). Leukocytes composed mainly of macrophages and neutrophils infiltrate infected DRGs and account for the development of herpetic neuralgia. Infiltrating leukocytes are responsible for driving the production of TNF, which in turn mediates the development of herpetic neuralgia through downregulation of the inwardly rectifying $\mathrm{K}^{+}$ channel Kir4.1 in satellite glial cells. These results revealed that neuroimmune-glia interactions at the sensory ganglia play a critical role in the genesis of herpetic neuralgia. In conclusion, the present study elucidates novel mechanisms involved in the genesis of acute herpetic pain and open new avenues for its control.

Key words: glial cells; herpes; inflammation; pain

Significance Statement

Acute herpetic neuralgia is the most important symptom of herpes zoster disease and it is very difficult to treat. Using a model of peripheral infection of mice with HSV-1, we have characterized for the first time the neuroimmune-glia interactions in the sensory ganglia that account for the development of acute herpetic neuralgia. Among these mechanisms, leukocytes composed mainly of macrophages and neutrophils infiltrate infected sensory ganglia and are responsible for driving the production of TNF. TNF, via TNFR1, mediates herpetic neuralgia development through downregulation of the inwardly rectifying $\mathrm{K}^{+}$channel Kir4.1 in satellite glial cells. This study elucidates novel mechanisms involved in the genesis of acute herpetic neuralgia and open new avenues for its control.

\section{Introduction}

Herpes zoster is a disease caused by reactivation of Varicella zoster virus in the sensory ganglia and it is usually accompanied by acute pain, namely, herpetic neuralgia. The viruses replicate in the gan-

Received July 13, 2016; revised May 20, 2017; accepted May 25, 2017.

Author contributions: J.R.S., A.H.L., J.T., G.L., B.A.F., E.A., J.C.A.-F., F.Q.C., and T.M.C. designed research; J.R.S., A.H.L., J.T., N.T.C., M.F.R., R.L.S., G.R.S., C.R.S., and T.M.C. performed research; J.R.S., B.A.F., and T.M.C. contributed unpublished reagents/analytic tools; J.R.S., J.T., N.T.C., M.F.R., and T.M.C. analyzed data; J.R.S., J.T., F.Q.C., and T.M.C. wrote the paper.

This work was supported by the São Paulo Research Foundation (FAPESP Grant 2010/12309-8, 2011/19670-0 for the thematic project and Grant 2013/08216-2 to the Center for Research in Inflammatory Disease); the University of São Paulo NAP-DIN (Grant 11.1.21625.01.0); and the European Union Seventh Framework Programme (FP7-20072013 Grant HEALTH-F4-2011-281608 TIMER); and by the 2011 International Association for the Study of Pain (Early Career Grant Award to T.M.C.). J. R.S was a recipient of a fellowship from FAPESP and CNPq. We thankSergio R. Rosa, Katia Santos, and Maria Lúcia Silva for technical assistance.

The authors declare no competing financial interests. glion and move antidromically along primary afferents to the skin, which results in a vesicopapular eruption in the corresponding cutaneous dermatome (Opstelten et al., 2010; Nagel and Gilden, 2014). Herpetic neuralgia is typically described as continuous aching and burning and often superimposed by allodynia, a severe lancinating pain that is precipitated by touching or moving the involved area (O'Connor and Paauw, 2013). Early treatment with antiherpetic agents such as acyclovir and vidarabine shorten the duration of skin lesions and complications related to herpes zoster (Tyring, 2007). Although nonsteroidal anti-inflammatory

Correspondence should be addressed either Thiago Mattar Cunha or Fernando de Queiroz Cunha, Pharmacology Department, Ribeirao Preto Medical School, University of Sao Paulo, Avenida Bandeirantes, 3900, 14040900 Ribeirao Preto, Sao Paulo, Brazil. E-mail: thicunha@fmrp.usp.br or fdqcunha@fmrp.usp.br. DOI:10.1523/JNEUROSCI.2233-16.2017

Copyright $\odot 2017$ the authors $\quad 0270-6474 / 17 / 376408-15 \$ 15.00 / 0$ 
drugs (NSAIDs), antidepressants, and sympathetic nerve blockers are used for the management of herpetic neuralgia, these treatments do not always relieve severe pain (Gan et al., 2013). The underlying pathophysiological mechanisms of spontaneous and evoked pain in herpes zoster are not well understood. However, because of species specificity of $V$. zoster, there is no animal model that correspond to human herpes zoster and herpetic neuralgia (Colleoni and Sacerdote, 2010; Gilden et al., 2011).

Similar to V. zoster, Herpes Simplex Virus Type-1 (HSV-1) is a neurotropic virus that invades the peripheral terminals of sensory neurons, reaching sensory ganglia via axonal transport (Wilson and Mohr, 2012). Because of the low species specificity, HSV-1 can infect rodents as well as humans and can be used as a murine model of $V$. zoster infection. After cutaneous infection of HSV-1, mice develop a zosteriform-like skin lesion, which is followed by herpetic pain-like behavior (Takasaki et al., 2000a; Takasaki et al., 2000b). This resembles some clinical and pathophysiological features of herpes zoster infection and could be used to study the immune mechanisms involved with the development of herpetic neuralgia (Takasaki et al., 2000b). Using this model of HSV-1 cutaneous infection, we describe here the neuroimmune-glia mechanisms occurring at the sensory ganglia accounting for the development of herpetic neuralgia.

\section{Materials and Methods}

Animals. The experiments were performed using male C57BL/6 or BALB/C WT mice (20-25 g); LysM-eGFP mice, which carry a knock-in mutation for enhanced green fluorescent protein (eGFP) in the lysozyme M-locus (Faust et al., 2000); mice deficient in TNFR1 (Tnfr $1^{-1}{ }^{-}$); mice deficient for MHC-II expression (Madsen et al., 1999; CD4-null mice); and mice deficient for $\beta 2$-microglobulin (Freland and Ljunggren, 2000; CD8-null mice), all of which were in C57BL/6 background (backcrossed at least 10 generations). The mice were housed in the animal care facility of the Ribeirao Preto Medical School and taken to the testing room at least $1 \mathrm{~h}$ before experiments. Food and water were available ad libitum. All behavioral tests were performed between 9:00 A.M. and 5:00 P.M. Animal care and handling procedures were in accordance with the guidelines of the International Association for the Study of Pain on the use of animals in pain research. Approval for ethical animal care and use was obtained before this study commenced (Process 105/2010 and 135/2016).

Virus preparation. HSV-1 used in this work was isolated from a patient with oral herpes treated at the Hospital of Ribeirao Preto Medical School (HC-FMRP). The virus was propagated in adenocarcinomic human alveolar basal epithelial cells (A549) cultured in complete DMEM. The virus was inoculated directly onto the cell monolayer. After observation of an $80 \%$ cytopathic effect, the supernatant and the cells were removed, the cells were lysed by freezing and thawing, and this solution containing the virus was aliquoted and frozen at $-70^{\circ} \mathrm{C}$ for use in subsequent passages or to perform virus titration. The viruses obtained in the passages were titrated to determine the virus concentration used in mice infection experiments. Virus suspensions were prepared from $10^{-1}$ to $10^{-10} \mathrm{di}-$ lution in sterile PBS and were added to 24-well plates containing Vero cells. After $1 \mathrm{~h}$, the inoculum was removed and the overlay medium added. The plates were incubated at $37^{\circ} \mathrm{C}$ for $1-2 \mathrm{~d}$ for observation of cytopathic effects and formation of lysis plaques. After this period, the wells were stained with Giemsa solution at 10\% (5\% acetic acid) and the plaques were counted for calculation of virus plaque-forming units (PFUs)

HSV-1 infection. Mice were anesthetized with isoflurane (2\%) and then the midflank and right foot were clipped and depilated with a chemical depilatory (Veet Hair Remover; Reckitt Benckiser). Three days later, HSV-1 $\left(2 \times 10^{5}\right.$ PFUs in $\left.20 \mu \mathrm{l}\right)$ was inoculated on the shin of the right hindpaw $(5 \times 5 \mathrm{~mm})$ after scarification with sandpaper. The virus was applied directly to the scarified area. The contralateral hindpaw was without inoculation. Mock infection was performed as described for HSV-1 infection except the virus used was inactivated previously by heating at $60^{\circ} \mathrm{C}$ for $1 \mathrm{~h}$

Nociceptive behavior test. The mechanical nociceptive threshold was tested in mice using von Frey filament test as described previously (Cunha et al., 2004). Briefly, mice were placed in acrylic cages $(12 \times 10 \times$ $17 \mathrm{~cm}$ ) with wire grid floors 15-30 min before the start of testing. In these experiments, a series of von Frey filaments (Stoelting) with logarithmically increasing stiffness $(0.9-3 \log$ of force, $\mathrm{mg})$ were applied perpendicularly to one of the five distal footpads with a gradual increase in pressure. The tests consisted of poking the hindpaw to provoke a flexion reflex, followed by a clear flinch response after paw withdrawal. Each von Frey filament was applied for $\sim 3-4 \mathrm{~s}$ to induce the endpoint reflex. The weakest filament able to elicit a response was considered to be the mechanical nociceptive threshold (log $\mathrm{mg}$ ).

Drugs. The following drugs were obtained from the sources indicated. Dexamethasone, fucoidin, fluorocitrate, and indomethacin were from Sigma-Aldrich. Morphine and lidocaine were from Cristalia Pharmaceuticals. Infliximab and etanercept were from ScheringPlough Pharmaceuticals. Murine anti-TNF was from eBioscience. Clodronate-encapsulated liposomes and control liposomes were from Encapsula Nanosciences.

The anti-Ly6G mAb (Gr-1-specific RB6-8C5 hybridoma) was produced in athymic nude BALB/c mice using the mouse ascites method (Daley et al., 2008). Antibody was purified by ammonium sulfate precipitation, dialyzed against PBS, and sterilized by $0.2 \mu$ filtration. Protein concentration was determined by BCA protein assay (Pierce). Mice were injected intraperitoneally with ammonium-sulfate-precipitated RB6-5C ascites containing $100 \mu \mathrm{g}$ of protein. Control animals were injected with IgG antibody isotype.

Intrathecal injection. Intrathecal injections $(5 \mu \mathrm{l})$ were made under anesthesia with $2 \%$ isoflurane using a $30 \mathrm{Ga}$ needle in a shaved area correspondent to L5/L6. The local anesthetic was considered sufficient when, after insertion of needle, mice presented a tail reflex (Mestre et al., 1994). It is noteworthy that none of the intrathecal treatments promoted locomotor or nociceptive impairment, demonstrating that the technique does not cause functional changes in the animal.

Viral load quantification. The absolute quantification of viral load was performed by real-time PCR. Briefly, infected mice were anesthetized followed by perfusion with PBS. DRGs L2, L3, L4, L5, and L6 ipsilateral to the infection, as well as spinal cord and contralateral DRGs, were removed and homogenized. The DNA extraction was performed with a commercial kit (Qiagen) and the viral load was determined by absolute quantification using as reference a plasmid standard curve containing the polymerase gene of HSV-1. Real-time PCR was performed using primers specific for the HSV-1 polymerase gene. Reactions were conducted on the ABI Prism 7500 Sequence Detection System using the SYBR-green fluorescence system (Applied Biosystems). The primer pair for HSV-1 polymerase gene was as follows: forward: $5^{\prime}$-GCTCGAGTGCGAAAAAAC GTTC-3' and reverse: 5' -TGCGGTTGATAAACGCGCAGT-3'.

RNA extraction and real-time PCR. At the indicated times after infection, infected mice were anesthetized and then perfused with PBS. DRGs L3, L4, L5, and L6 ipsilateral to the infection were collected and analyzed as a pool. The samples were homogenized in $1 \mathrm{ml}$ of TRIzol (Invitrogen) and total RNA was extracted following the manufacturer's instructions. The purity of total RNA was measured with a spectrophotometer and the wavelength absorption ratio $(260 / 280 \mathrm{~nm})$ was between 1.8 and 2.0 for all preparations. Reverse transcription of total RNA to cDNA was performed with a reverse transcription reaction (Superscript II; Invitrogen Life Technologies). Real-time PCR was performed using primers specific for the mouse genes Tnf, Kcnj10, Gfap, and Ptgs2, and for the mouse housekeeping gene Gapdh. Reactions were conducted on the ABI Prism 7500 Sequence Detection System using the SYBR-green fluorescence system (Applied Biosystems). The data were analyzed with the $2^{-\Delta \Delta \mathrm{Ct}}$ method as described previously and expressed relative to samples collected in the naive group of animals. Primer pairs for mouse Tnf, Ptgs2, Gfap, Kcnj10, and Gapdh were as follows: Tnf forward: 5'-TGTGCTCAGAGCTTTC AACAA-3'; Tnf reverse: 5'-CTTGATGGTGGTGCATGAGA-3'; Ptgs2 forward: 5'-GTGGAAAAACCTCGTCCAGA-3'; Ptgs2 reverse: 5'-GCT CGGCTTCCAGTATTGAG-3'; Gfap forward: 5'-AGGGCGAAGAAA 
ACCGCATCACC-3'; Gfap reverse: 5'-CGGCCAAATCCGTTCAC-3'; Kcnj10 forward: 5'-GTGACAGGCAAACTGCTTCA-3; Kcnj10 reverse: 5'-GGGCTATCAGAGGCTGTGTC-3; Gapdh forward: 5'-CATCTTC TTGTGCAGTGCCA-3'; and Gapdh reverse: 5'-CGGCCAAATCCGTT CAC-3'.

Flow cytometry analysis. DRGs L3, L4, L5, and L6 were collected from infected mice and analyzed as a pool. DRGs were prepared as single-cell suspensions according to standard protocols. Briefly, DRGs were incubated in colagensase for $75 \mathrm{~min}$ at $37^{\circ} \mathrm{C}$. After this time, the tissues were digested through vortex and $1 \mathrm{ml}$ of RPMI medium (10\% SBF) was added to the cell suspension containing collagenase. The cells were washed once with PBS and then suspended and incubated for $30 \mathrm{~min}$ at $4^{\circ} \mathrm{C}$ in PBS containing 2\% BSA and FcgRI block mAb (CD16/CD32) to avoid nonspecific background staining. The following monoclonal antibodies (BD Biosciences) were used for staining: APC rat anti-mouse CD45, PE rat anti-mouse Ly6-G/Gr-1, FITC rat anti-mouse F4/80, FITC rat anti-mouse $\mathrm{CD} 4$, and $\mathrm{PE}$ rat anti-mouse $\mathrm{CD} 8$. Flow cytometry was performed in a FACSCanto instrument (BD Biosciences) and analyzed with FlowJo software (TreeStar).

Western blot analysis. DRGs L3, L4, L5, and L6 were collected, pooled, and homogenized in a lysis buffer containing a mixture of protease inhibitors and phosphatase inhibitors (Sigma-Aldrich). The protein concentrations of the lysate were determined using a BCA Protein Assay kit (Pierce) and $30 \mu \mathrm{g}$ of protein was loaded for each lane. Protein samples were separated on a SDS-PAGE gel (10\% gradient gel; Bio-Rad) and transferred to nitrocellulose membranes (GE Healthcare). The filters were blocked with $5 \%$ dry milk and incubated overnight at $4^{\circ} \mathrm{C}$ with a primary antibodies against COX-2 (1:500; Abcam), GFAP (1:1000; Cell Signaling Technology), and Kir4.1 (APC035A; Alomone). The membranes were washed and incubated for $2 \mathrm{~h}$ at room temperature with an HRP-conjugated secondary antibody (1:10000; Jackson ImmunoResearch). Immunodetection was performed using an enhanced chemiluminescence light-detecting kit (GE Healthcare) for $1 \mathrm{~min}$. A mouse monoclonal antibody against $\beta$-actin (1:10000; Sigma-Aldrich) was used for loading controls. Images were used as representative blots. Densitometric data were measured after normalization to the control (housekeeping gene) using Scientific Imaging Systems Image labTM 3.0 software (BioRad).

$D R G$ immunohistochemistry. Mice were terminally anesthetized with ketamine/xylazine and perfused through the ascending aorta with saline, followed by $4 \%$ paraformaldehyde in $0.1 \mathrm{~m}$ phosphate buffer, $\mathrm{pH} 7.4$ $\left(4^{\circ} \mathrm{C}\right)$. After the perfusion, DRGs L4 and L5 were removed and postfixed in the same fixative for $2 \mathrm{~h}$, which was then replaced overnight with $20 \%$ sucrose. DRGs were embedded in OCT and sections $(14 \mu \mathrm{m})$ were cut in a cryostat and processed for immunofluorescence. All of the sections were blocked with $1 \%$ BSA in $0.1 \%$ Triton X-100 for $1 \mathrm{~h}$ at room temperature and incubated overnight at $4^{\circ} \mathrm{C}$ with the following antibodies: mouse anti-TNFR1 (clone 55R-28, 1:400; Biolegend), mouse anti-TNFR1 (sc-8436; Santa Cruz Biotechnology), rabbit anti-glutamine synthase (GS, 1:400; AB73593; Abcam), rabbit anti-Kir4.1 (APC035A; Alomone) or goat anti-GFP (1:100, AB6662; Abcam). After washing, a mixture of Alexa Fluor 488- and Alexa Fluor 594-conjugated secondary antibodies (Invitrogen/Thermo Scientific) were added for $2 \mathrm{~h}$ at room temperature. Finally, the slides were coverslipped with Fluoromount and sealed with enamel. The absence of cross-reactivity of the secondary antibodies was verified by omitting primary antibody during incubation. Doublelabeled sections were analyzed by confocal laser microscope (TCS SP5; Leica). Color images from double-labeling experiments were adjusted for contrast and brightness using Adobe Photoshop 9.0 software.

Generation of bone-marrow (BM)-chimeric mice. Recipient mice were exposed to 9-gray total-body irradiation using a source gamma irradiation (Mark I Model 25 Gamma Irradiator; J.L. Shepherd and Associates). One day later, the animals were injected via tail vein with $5 \times 10^{6} \mathrm{BM}$ cells freshly collected from donor mice. The cells were aseptically harvested by flushing femurs with Dulbecco's PBS (DPBS) containing $2 \%$ fetal bovine serum. The samples were combined, filtered through a 40 $\mu \mathrm{m}$ nylon mesh, centrifuged, and passed through a 25 gauge needle. Recovered cells were resuspended in DPBS at a concentration of $4 \times 10^{6}$ vial nucleated cells per $200 \mu$ l. Irradiated mice transplanted with this suspension were housed in autoclaved cages and treated with antibiotics
(10 mg of ciprofloxacin per milliliter of drinking water given for 2 weeks after irradiation). Mice were subjected to HSV-1 infection 8 weeks after transplantation. The chimeric mice were generated as follows (donor $\rightarrow$ recipient): (1) WT and Tnfr $1^{-1-}$ recipient mice transplanted with BM from WT donor mice $\left(\mathrm{WT} \rightarrow \operatorname{Tnfr} 1^{-1}-\right.$ and WT $\left.\rightarrow \mathrm{WT}\right)$, and $(2) \mathrm{WT}$ and $\mathrm{Tnfr} 1^{-1-}$ recipient mice transplanted with BM from $\mathrm{Tnfr} 1^{-1-}$ donor mice $\left(\operatorname{Tnfr} 1^{-1-} \rightarrow\right.$ WT and Tnfr1 $1^{-1-} \rightarrow \operatorname{Tnfr} 1^{-1-}$ ).

Satellite glial cell (SGC) culture. Mice were terminally anesthetized with ketamine/xylazine and DRGs were collected and processed. Cells were dissociated and plated in six-well plastic plates coated with Matrigel (BD Biosciences). The SGCs were isolated according to an adapted version of a published protocol (Belzer et al., 2010). The purity was $95-97 \%$ as confirmed by the expression of glutamine synthase.

Generation of ShRNA-Kir4.1. Short hairpin RNA (shRNA) was used to silence the murine expression of Kir4.1 in vivo. Five psiRNA clones were generated using psiRNA-h7SK vector (InvivoGen). The most efficient was against the sequence $5^{\prime}$-GGTACCTTCCTTGCAAAGATT-3' . A scrambled sequence targeting the luciferase GL3 reporter gene (not complementary to any mouse genes) was used as a control shRNA (sc-shRNA). The psiRNA-h7SK plasmids were mixed with PEI (In Vivo Jet-PEI; Polyplus Transfection) according to the manufacturer's instructions. The N:P ratio (number of nitrogen residues of In Vivo Jet-PEI per DNA phosphate) used was 6 ( $1 \mu \mathrm{g}$ of DNA was mixed with $0,12 \mu \mathrm{l}$ of In Vivo Jet-PEI). The $\mathrm{PEI} /$ plasmid polyplex solution ( $5 \mu \mathrm{l} / \mathrm{animal})$ was carefully administered intrathecally on anesthetized naive mice during 5 consecutive days, as described previously (Njoo et al., 2014). The efficacy of ShRNA against Kir4.1 was confirmed by Western blotting analyses in mouse DRGs (L3-L6).

Data analyses and statistics. Data are reported as means \pm SEM. Twoway ANOVA was used to compare the groups and doses at the different times (curves) when the responses (nociception) were measured after infection. The analyzed factors were treatments, time, and the time versus treatment interaction. The normality of data was analyzed by the D'Agostino and Pearson test, which confirmed the parametric distribution of data. If there was a significant time versus treatment interaction, one-way ANOVA followed by Tukey's $t$ test was performed for each time. Alternatively, if the responses (nociception, protein expression, and mRNA expression) were measured only once after the stimulus injection, the differences between responses were evaluated by one-way ANOVA followed by Tukey's $t$ test (for three or more groups) comparing all pairs of columns. $p<0.05$ was considered significant. Statistical analysis was performed with GraphPad Prism software.

\section{Results}

Predictive validity of $\mathrm{HSV}-1$ cutaneous infection as a model of herpetic neuralgia in mice

We analyzed the temporal pattern of skin lesion, pain-like responses (mechanical hypersensitivity), and viral load in the DRGs after skin infection of mice with HSV-1. HSV-1 skin infection promotes the development of zosteriform-like lesions in $60 \%(n=12 / 20)$ of mice, which can be visualized from $5 \mathrm{~d}$ postinfection (dpi), progressing until $8 \mathrm{dpi}$ (Fig. 1A) and disappearing at $21 \mathrm{dpi}$ (Fig. $1 A$ ). No zosteriform-like skin lesions were observed in the contralateral side of infection or in mice infected with mock virus (inactivated, data not shown). Skin lesions were accompanied by a temporal increase in viral loads at the corresponding DRGs. Viral genomic material was detected in the DRGs 3 dpi and the higher levels were at $7 \mathrm{dpi}$. No viral load was detected at late stages of infection (21 dpi) (Fig. 1B). In addition, HSV-1 can be detected in lumbar DRGs (L2-L6), with the largest amount of viral genomic material detected in L5 (Fig. 1C).

Mice infected with HSV-1, but not with the mock virus, developed herpetic pain hypersensitivity in the ipsilateral paws (Fig. $1 D)$. The HSV-1-infected mice did not develop mechanical hypersensitivity in the contralateral paws, suggesting that herpetic neuralgia development is specific for the corresponding neurodermatome. The mechanical hypersensitivity caused by HSV-1 
A
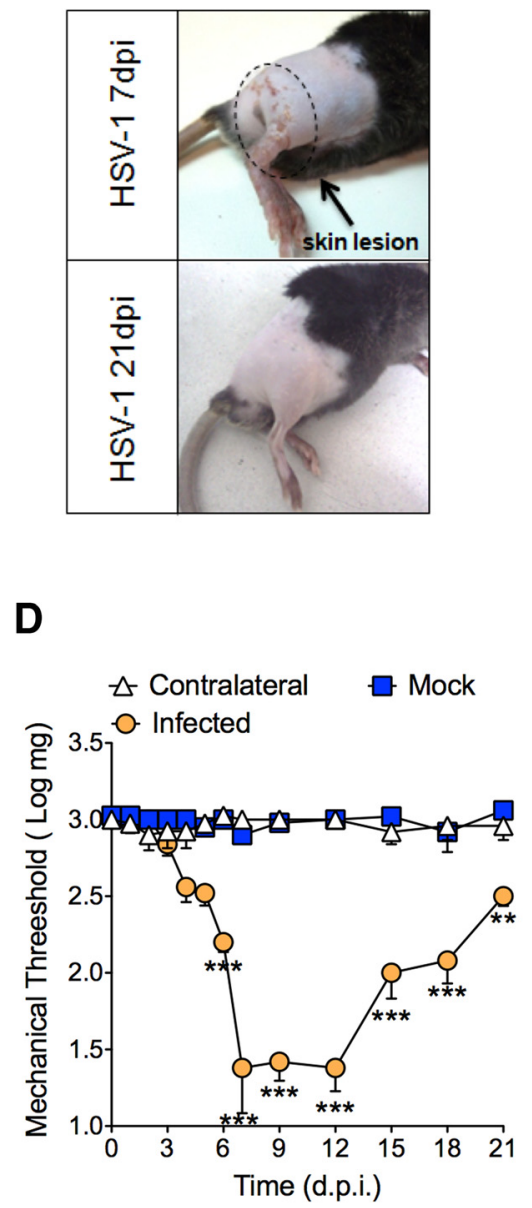

B

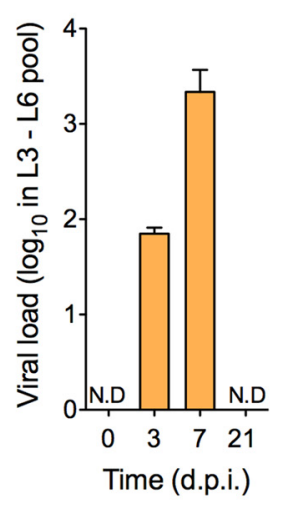

C

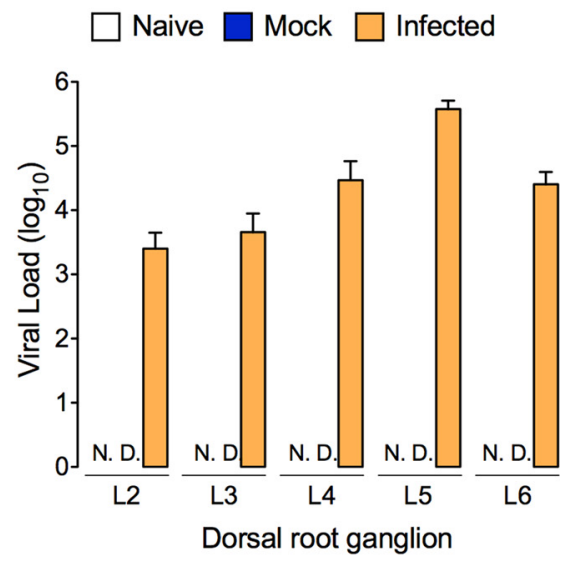

$\mathbf{E}$

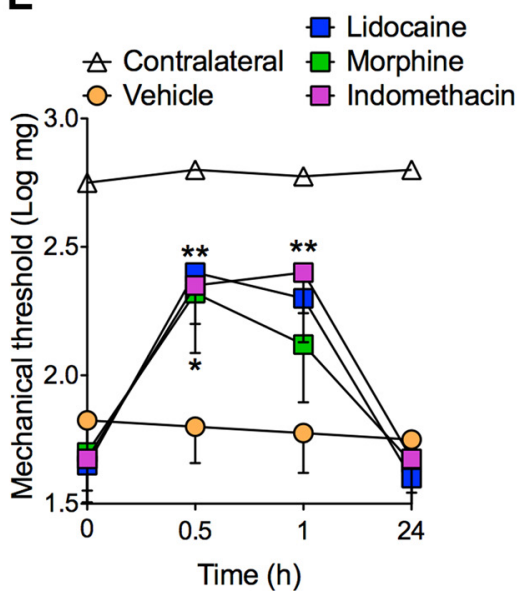

Figure 1. Characterization of HSV-1 peripheral-infection-induced herpetic neuralgia in mice. C57BL/6 male mice were inoculated with $\mathrm{HSV}-1\left(2 \times 10^{5} \mathrm{PFUs}\right)$ or mock virus on the shin of the right hindpaw. A, Representative photographs of skin zosteriform-like lesion at 7 and 21 dpi. B, HSV-1 viral load in the DRGs of infected mice at 7 and 21 dpi. The viral load was measured in pooled L3-L6 DRGs from individual mice ( $n=5$ mice for each time point). C, Viral load in individual $L 2, L 3, L 4, L 5$, and L6 DRGs of infected mice at 7 dpi $(n=5$ mice per group). $D$, Values of mechanical nociceptive threshold (log mg) of infected C57BL/6 mice from 0 to $21 \mathrm{dpi}$ ( $n=6$ mice per group). $E$, Infected C57BL/6 mice ( $n=5$ mice per group) were treated with lidocaine (20 ng, surrounding the lesion), morphine (5 mg/kg, i.p.) or indomethacin $(5 \mathrm{mg} / \mathrm{kg}$, i.p.) at $7 \mathrm{dpi}$. Mechanical nociceptive thresholds $(\mathrm{log} \mathrm{mg})$ were measured before and 30 and $60 \mathrm{~min}$ after treatments. Data are expressed as the mean \pm SEM. ${ }^{*} p<0.05 ;{ }^{* *} p<0.01 ;{ }^{* *} p<0.001$ for differences between infected versus mock and infected versus naive mice $(\boldsymbol{D})$ or infected mice treated with lidocaine, morphine, and indomethacin compared with vehicle mice (two-way ANOVA, Bonferroni's post test). Data are representative of six $(\boldsymbol{A})$, three $(\boldsymbol{B}, \boldsymbol{C}, \boldsymbol{E})$, or two $(\boldsymbol{D})$ experiments; ND, Not detectable.

infection was significant from $4 \mathrm{dpi}$, progressed until $12 \mathrm{dpi}$, and returned to the control levels at $21 \mathrm{dpi}$ (Fig. 1D). The pharmacological predictive validity of this model was evaluated using different analgesic or anesthetic drugs used in clinical practice. At day seven after HSV-1 peripheral infection, mice were treated with morphine (an opioid), indomethacin (an NSAID), and lidocaine (a local anesthetic). All treatments resulted in a significant and transient reduction in mechanical hypersensitivity (Fig. 1E).

\section{Leukocyte infiltration in the DRGs accounts for herpetic neuralgia}

Because, after peripheral infection, HSV-1 reaches the sensory ganglia, we evaluated whether this could lead to an immune response at the DRGs. HSV-1 peripheral infection promotes a progressive infiltration of leukocytes (CD45+ cells) starting from 5 dpi, which increase at $7 \mathrm{dpi}$ (Fig. 2A). Interestingly, no significant infiltration of immune cells (CD45+ cells) was observed in the spinal cord at 5 and $7 \mathrm{dpi}$ (Fig. $2 B$ ). These results suggest that, at these time points, if leukocytes were important for herpetic neu- ralgia, then the DRG infiltration would be the major site involved in this process.

It was found that macrophages and neutrophils are the main types of leukocytes in the DRGs at 7 dpi (Fig. 2C,D). Whereas neutrophil infiltration was maximum at $7 \mathrm{dpi}$, returning to the control levels thereafter, macrophage infiltration is still significant at $14 \mathrm{dpi}$ and normalizes at $21 \mathrm{dpi}$ (Fig. 2E). Indeed, the massive infiltration of neutrophils and macrophages can be visualized in the DRGs of HSV-1-infected LysM-eGFP mice (Fig. $2 F, G$ ).

To determine whether inflammatory response and leukocyte recruitment to DRGs are involved in the cascade of events in the development of herpetic neuralgia, HSV-1-infected mice received an intrathecal treatment with a broad-spectrum anti-inflammatory agent, the corticosteroid dexamethasone. Intrathecal treatment with dexamethasone reduced HSV-1-induced mechanical hypersensitivity (Fig. 3A). Systemic treatment with the same amount of dexamethasone did not change HSV-1-induced mechanical hypersensitivity, suggesting that intrathecal dose of dexamethasone does work locally, probably at the level of DRGs. The reduction of HSV-1-induced 


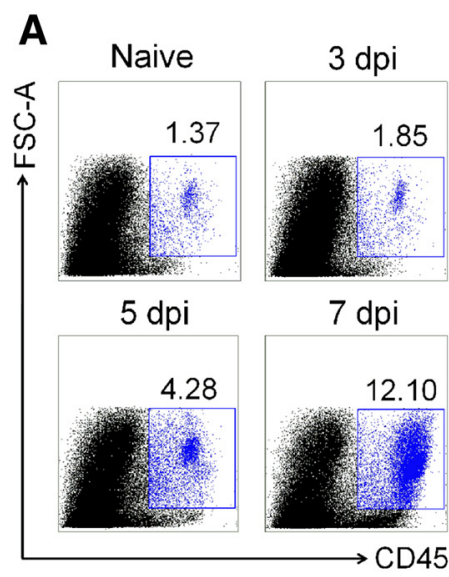

C

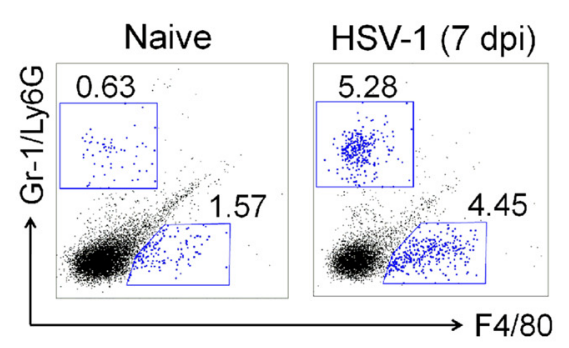

$\mathbf{F}$

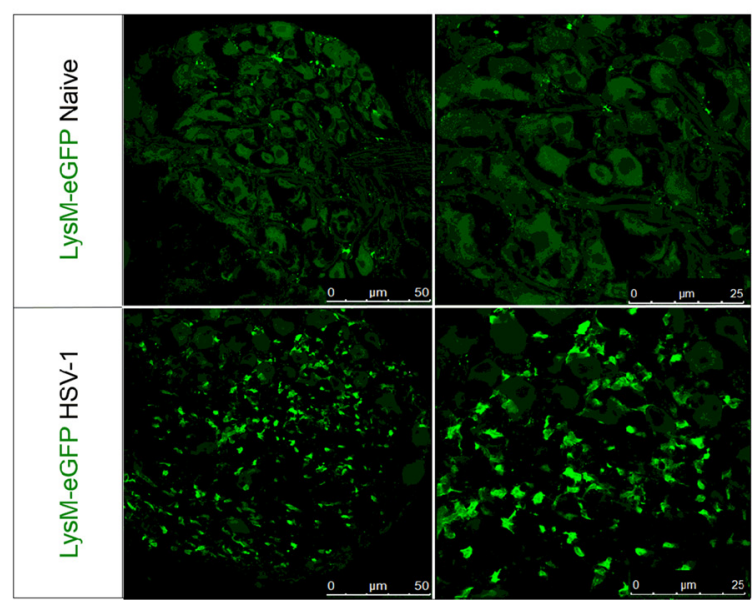

B

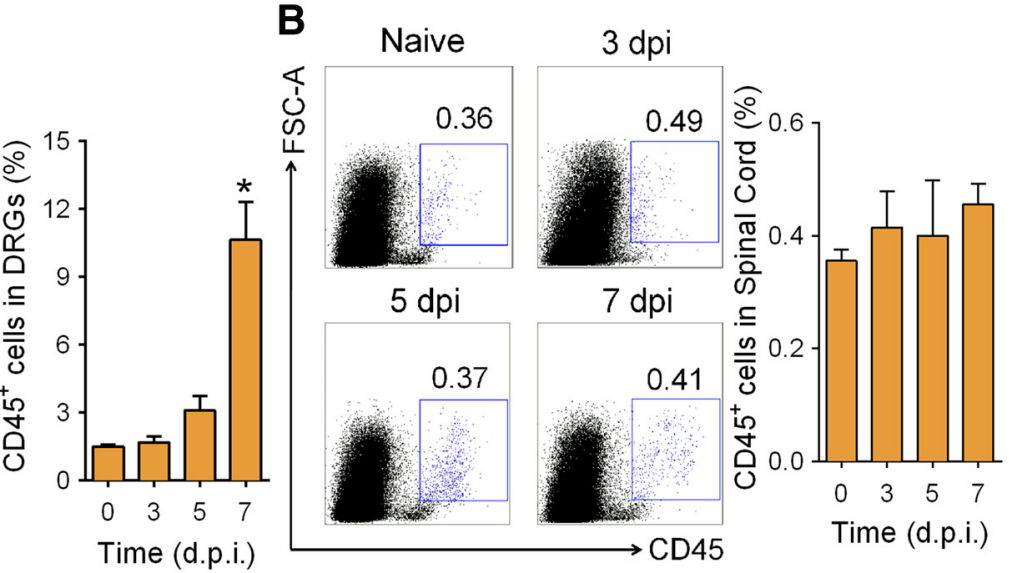

D

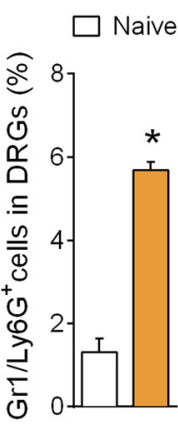

G
E
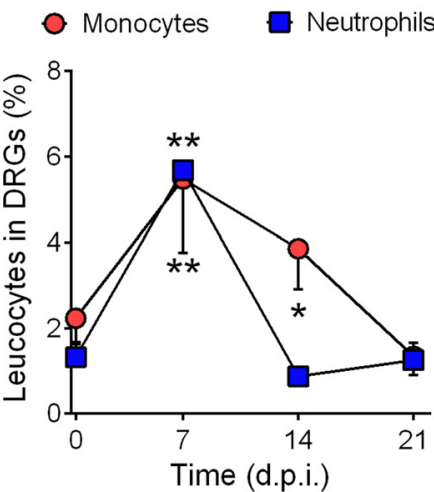

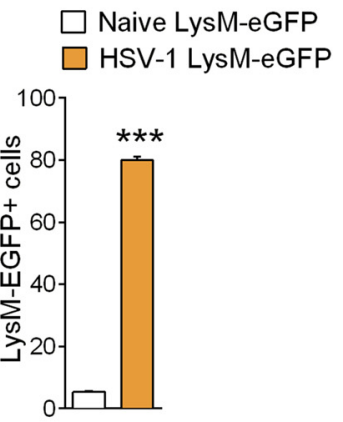

Figure 2. Leukocyte infiltration in DRGs after peripheral infection with HSV-1. C57BL/6 male mice were inoculated with HSV-1 ( $2 \times 10^{5}$ PFUs) on the shin of the right hindpaw. At 3,5 , and 7 dpi, DRGs L3 - L6 and spinal cord were collected and flow cytometry was performed ( $n=5$ mice for each time point). Representative dot plots and quantification of leukocyte (CD45 + ) infiltration in DRGs $(\boldsymbol{A})$ and spinal cord (B) of HSV-1-infected mice. C, Representative dot plot of macrophages (Gr1/Ly6 - G -/F4/80 + cells) and neutrophils (Gr1/Ly6 - G +/F4/80 - cells) infiltration in DRGs at 7 dpi. $\boldsymbol{D}$, Frequencies of neutrophils and macrophages in infected DRGs at $7 \mathrm{dpi}$. $\boldsymbol{E}$, Time course of neutrophil and macrophage infiltration in DRGs. $\boldsymbol{F}$, Representative imunofluorescence for LysM-eGFPpositive cells in infected DRGs at 7 dpi. G, Quantification of LysM-eGFP cells in infected DRGs at $7 \mathrm{dpi}\left(n=4\right.$ mice per group). Data are expressed as the mean $\pm S E M .{ }^{*} p<0.05$; ${ }^{* *} p<0.01 ;{ }^{* * *} p<$ 0.001 for differences between the frequency of leukocytes in infected versus naive mice (Tukey's $t$ test). Data are representative of three $(\boldsymbol{A}-\boldsymbol{E})$ or two $(\boldsymbol{F}, \boldsymbol{G})$ experiments.

mechanical hypersensitivity promoted by intrathecal dexamethasone was associated with a reduction in leukocyte (CD45+ cells) infiltration into the DRGs (Fig. 3B,C). To further confirm the participation of leukocyte infiltration, HSV-1-infected mice were treated with fucoidin, a potent inhibitor of leukocyte rolling and migration. Similar to dexamethasone treatment, inhibition of leukocyte infiltration prevented the development of herpetic neuralgia (Fig. 3D). The effectiveness of fucoidin in inhibiting leukocyte migration into DRGs was further confirmed (Fig. $3 E, F)$.

To evaluate the specific role of the different leukocytes that were infiltrating into the DRGs, the depletion of these cells was performed with liposomes containing clodronate (for macrophage depletion) or with the antibody anti-Ly6G (for neutrophil 


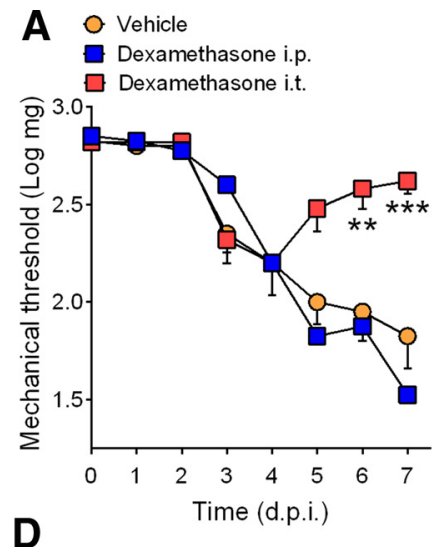

D

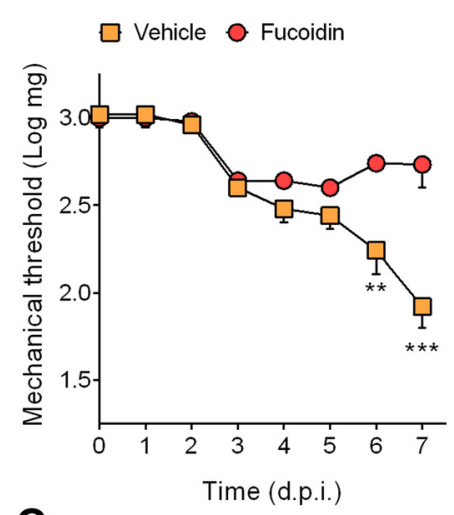

G

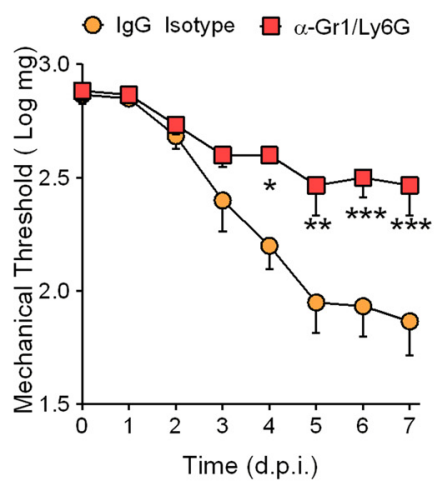

B

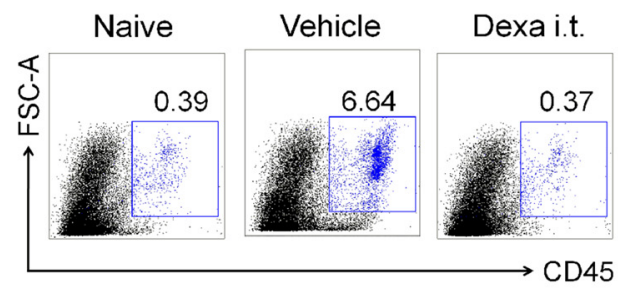

E

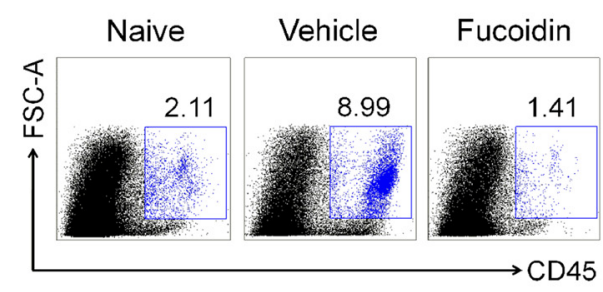

C $\square$ Vehicle

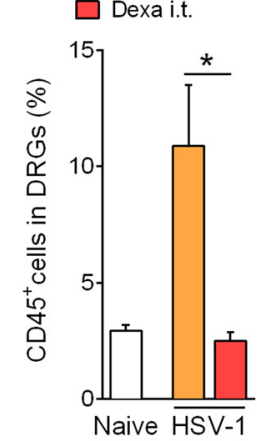

$\mathbf{F}$

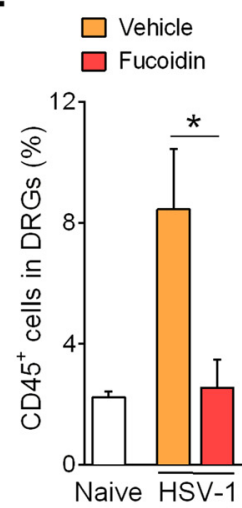

H

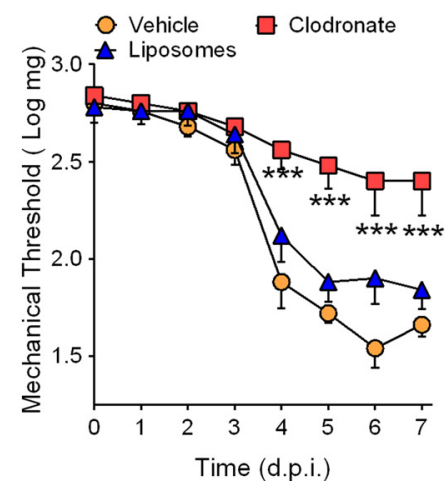

Figure 3. Leukocyte infiltration in the DRGs accounts for herpetic neuralgia. C57BL/ 6 male mice ( $n=5$ per group) were inoculated with HSV $-1\left(2 \times 10^{5}\right.$ PFUs) on the shin of the right hindpaw and treated daily with dexamethasone ( $5 \mu$ g, i.t. or i.p.) from 2 to 7 dpi. A, Mechanical nociceptive thresholds were determined at $0-7$ dpi. At 7 dpi, DRGs (L3-L6) were collected and flow cytometry was performed. Representative dot plots $(\boldsymbol{B})$ and frequencies $(\boldsymbol{C})$ of leukocyte infiltration $(C D 45+)$ in DRGs of vehicle- and dexamethasone $(5 \mu \mathrm{g}$, i.t.)-treated mice. Infected mice $(n=5$ per group) were treated daily with fucoidin ( $20 \mathrm{mg} / \mathrm{kg}$, i.v) or saline (vehicle) from 2 to $7 \mathrm{dpi}$. D. Mechanical nociceptive threshold was determined 0 to $7 \mathrm{dpi}$. At $7 \mathrm{dpi}$, DRGs (L3-L6) were collected, and flow cytometry was performed. Representative dot plots $(\boldsymbol{E})$ and frequencies $(\boldsymbol{F})$ of leukocyte infiltration (CD45 +$)$ in DRGs of vehicle- and fucoidin-treated mice. $\mathbf{G}$, Mice $(n=5$ per group) were treated daily with the antibody anti-Ly6-G ( $4 \mathrm{mg} / \mathrm{kg}$ i.p.), from 2 to $7 \mathrm{dpi}$. Mechanical nociceptive threshold was determined at $0-7$ dpi. $\boldsymbol{H}$, Mice $(n=5$ per groups) were treated daily with liposome/ clodronate (500 $\mu$ i.p. at 2 dpi; daily treatment from 3 to 7 dpi with $250 \mu$ g, i.p.) or empty liposomes from 2 to 7 dpi. Mechanical nociceptive threshold was determined at $0-7$ dpi. Data are expressed as mean \pm SEM. ${ }^{*} p<0.05 ;{ }^{* *} p<0.01 ;{ }^{* * *} p<0.001$ for differences between the nociceptive behavior of treated infected mice compared with vehicle infected mice $(\boldsymbol{A}, \boldsymbol{D}, \boldsymbol{G}, \boldsymbol{H}$, two-way ANOVA, Bonferroni's post test) or between the differences of leukocyte migration to DRGs of treated and vehicle mice ( $\boldsymbol{C}$, $\boldsymbol{F}$; one-way ANOVA, Tukey's $t$ test). Data are representative of two $(\boldsymbol{A}-\boldsymbol{F})$ or three $(\boldsymbol{G}-\boldsymbol{H})$ experiments.

depletion) (Stirling et al., 2009; van Rooijen and Hendrikx, 2010). Neutrophil- and macrophage-depleted mice presented a reduction in mechanical hypersensitivity compared with each control group (Fig. 3G,H). Despite the detection of neutrophils and macrophages in DRGs, only a small infiltration of CD4+ T lymphocytes was detected in DRGs, whereas CD8 + T lymphocytes were absent (Fig. $4 A, B$ ). Importantly, there was no difference in HSV-1 infection-induced mechanical pain hypersensitivity in CD4+ and CD8+ T-cell-null mice compared with WT mice (Fig. $4 C, D$ ). Altogether, these data indicate that an immune re- sponse in the sensory ganglia after cutaneous infection with HSV-1 is mainly represented by cells of innate immunity, notably neutrophils and macrophages. Furthermore, infiltration of these immune cells into the DRGs plays an important role in the development of acute herpetic neuralgia.

Infiltrating leukocytes drive TNF production in the DRGs that is essential for the development of herpetic neuralgia One possible mechanism by which leukocyte infiltration into the sensory ganglia participate in the genesis of herpetic neuralgia is 
through the production of pronociceptive mediators such as TNF. In fact, TNF production in the sensory ganglia plays an important role in the genesis of inflammatory and neuropathic pain conditions (Schäfers et al., 2003). We initially evaluated the temporal expression of $\operatorname{Tnf}$ mRNA in the DRGs of infected mice and observed a time-dependent upregulation of this cytokine in DRGs ipsilateral to the HSV-1 cutaneous infection. The peak of expression occurred at $7 \mathrm{dpi}$, and decreased at 21 dpi (Fig. 5A), and was restricted to the ipsilateral DRGs; it was not observed in the contralateral DRGs (Fig. $5 B)$.

The intrathecal treatment with neutralizing anti-TNF antibodies (infliximab or antimurine TNF) or with a soluble TNF receptor (etanercept) resulted in a significant reduction in the development of mechanical hypersensitivity compared with the respective control group (antibody isotype or vehicle) (Fig. 5C). Further, mice genetically deficient to TNF receptor type 1 $\left(\right.$ Tnfr $1^{-l^{-}}$) also showed reduced development of mechanical hypersensitivity compared with genetically sufficient mice (WT) (Fig. 5D). Interestingly, the treatment with fucoidin or depletion of neutrophils with antibody anti-Ly6G inhibited the expression of Tnf in DRGs (Fig. 5E,F). Conversely, Tnfr $1^{-1-}$ mice showed a similar infiltration of leukocytes into the infected DRGs compared with WT mice (Fig. 5G). Altogether, these results indicate that, after peripheral infection with HSV-1, DRGinfiltrating leukocytes trigger the local production of TNF that in turn mediates the development of acute herpetic neuralgia. Furthermore, they indicate that TNF/TNFR1 signaling is not necessary for the recruitment of leukocytes toward DRGs after HSV-1 peripheral infection.

Because the increase in the production of COX-2-derived products in the sensory ganglia are involved in the development of herpetic neuralgia (Takasaki et al., 2005), we next tested the hypothesis that TNF would mediate the induction of herpetic neuralgia through upregulation of prostaglandin component. First, we confirmed that there is an upregulation of cyclooxygenase-2 levels (mRNA and protein, respectively) in the DRGs after HSV-1 peripheral infection (Fig. 6A,B). Ptgs2 expression increase was only observed in ipsilateral DRGs (Fig. 6C). Moreover, a daily intrathecal treatment with indomethacin was able to reduce herpetic pain hypersensitivity (Fig. 6D). Surprisingly, Ptgs 2 mRNA expression in the DRGs was similar in Tnfr1 $1^{-1-}$ and WT infected mice (Fig. 6E). These results indicate that, although COX2-derived products mediate acute herpetic neuralgia, they are not triggered by TNF/ TNFR1 pathway.

\section{TNF/TNFR1 signaling in SGCs downregulates the expression of Kir4.1 channels}

Other possible mechanisms by which the TNF/TNFR1 signaling in the sensory ganglia mediates the development of acute herpetic neuralgia were evaluated. In this context, $\mathrm{BM}$ chimeric mice were generated to evaluate in which cell type TNFR1 activation might be important for driving acute herpetic neuralgia: in hematopoietic cells (infiltrating leukocytes) or in DRG-resident nonhematopoietic cells (Fig. 7A). The adoptive transfer of BM from WT mice to irradiated $\operatorname{Tnfr} 1^{-1-}$ mice did not recapitulate the mechanical hypersensitivity phenotype of irradiated WT mice that received BM from WT. Furthermore, when WT mice received BM from Tnfr $1^{-1-}$ mice, they still developed herpetic pain hypersensitivity (Fig. 7B). These results indicate that, during infection, TNFR1 activation in nonhematopoietic DRG-intrinsic cells accounts for the development of acute herpetic neuralgia. Indeed, the pattern of TNFR1 expression in the mice DRGs slices shows that this receptor is expressed mainly in GS-positive cells, which in DRGs is exclusively expressed in SGCs (Fig. 8A). Interestingly, it seems that TNFR1 is located in the cell membrane of SGCs (Fig. $8 A$, white arrow). Based on these results, our hypothesis was that TNF in the sensory ganglia mediates the genesis of acute herpetic neuralgia through modulation of SGC function. In fact, after peripheral infection with HSV-1, there was a time-dependent increase in the expression of Gfap mRNA (Fig. 8B) and protein (Fig. 8C), which suggested the activation of SGCs in the DRGs after peripheral HSV-1 infection. Intrathecal injection of fluorocitrate (from 2-7 dpi), which inhibited the activation of SGCs (Fig. 8D) but not Tnf expression in the sensory ganglia after HSV-1 infection (Fig. $8 E$ ), reduced herpetic pain hypersensitivity (Fig. $8 F$ ). However, the expression of Gfap mRNA in the DRGs of infected Tnfr $1^{-1-}$ mice was similar to the levels observed in WT mice (Fig. 8G). 
A

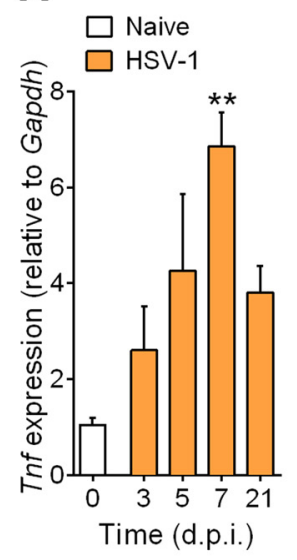

E

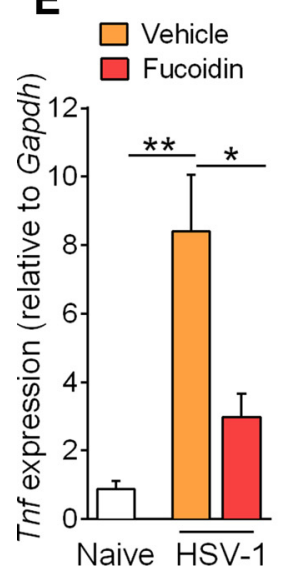

B

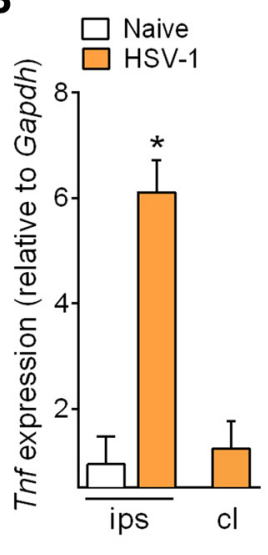

C

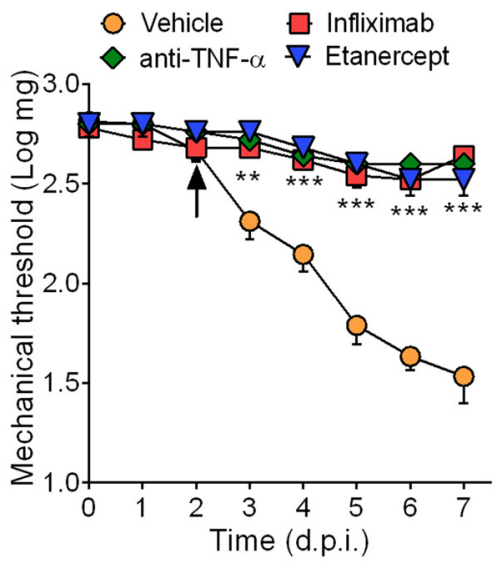

D

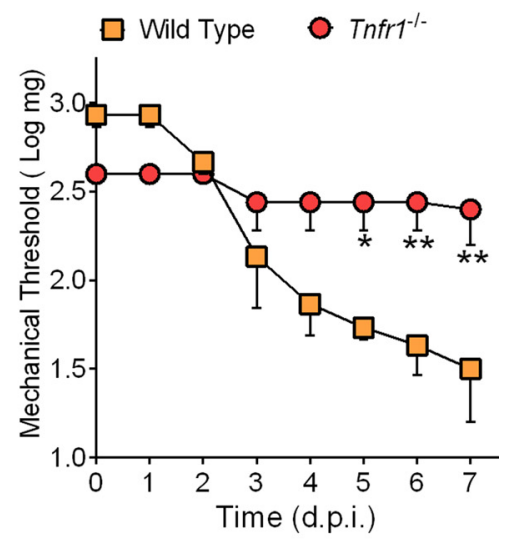

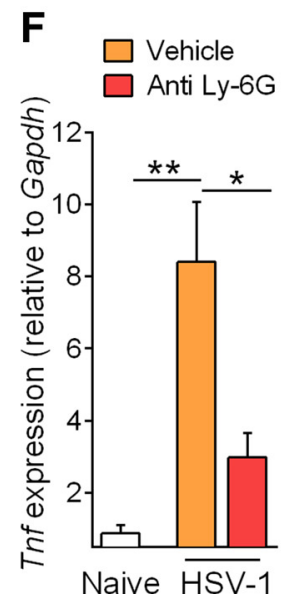

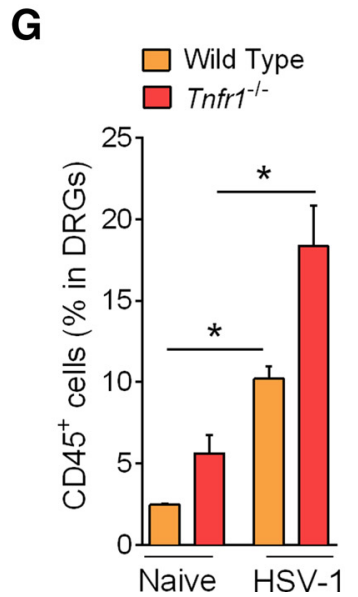

Figure 5. Infiltrating leukocytes drive TNF- $\alpha$ production in the DRGs, which is essential for the development of herpetic neuralgia. $\boldsymbol{A}$, At $0-21 \mathrm{dpi}, \mathrm{DRGs} \mathrm{L3}-\mathrm{L} 6 \mathrm{~W}$ were collected from infected mice ( $n=7$ mice for each time point) and RT-PCR was performed using primers for murine TNF- $\alpha$ gene (Tnf). Relative expression to Gapdh gene is shown. $\boldsymbol{B}$, Relative $\mathrm{mRNA}$ expression of Tnf in ipsilateral and contralateral DRGs (L3-L6) of infected mice and naive mice ( $n=6$ per group). $\boldsymbol{C}$, Infected mice ( $n=5$ per group) were treated daily with anti-TNF- $\alpha$ neutralizing antibodies ( $10 \mu$ g/in $5 \mu$ l of saline, i.t.) from 2 to $7 \mathrm{dpi}$. Mechanical nociceptive threshold was determined at $0-7 \mathrm{dpi}$. D, Mechanical nociceptive thresholds of WT and TNFR1 (Tnfr $1-/-)$ knock- out mice $(n=5$ per group) from 0 to 7 dpi. $\boldsymbol{E}, \boldsymbol{F}$, Relative mRNA expression of Tnf in DRGs (L3-L6) from infected mice ( $n=5$ per group) treated with fucoidin $(\boldsymbol{E})$ or vehicle $(\boldsymbol{F})$ anti-Ly6-G or control isotype. $\mathbf{G}$, Leukocyte $(C D 45+)$ infiltration in DRGs of WT and Tnfr $1^{-/-}$infected mice $\left(n=5\right.$ per group) at 7 dpi. Data are expressed as mean \pm SEM. ${ }^{*} p<0.05 ;{ }^{* *} p<0.01 ;{ }^{* * *} p<0.001$ for differences between the Tnf mRNA expression in infected DRGs $(\boldsymbol{A}, \boldsymbol{B}, \boldsymbol{E}, \boldsymbol{F}$; one-way ANOVA, Dunn's post test), the differences between the nociceptive behavior of infected mice ( $\boldsymbol{C}, \boldsymbol{D}$; two-way ANOVA, Bonferroni's post test) or between the differences of leukocyte migration to DRGs of TNFR1 ${ }^{-1-}$ and WT mice (G; one-way ANOVA, Tukey's $t$ test). Data are representative of two $(\boldsymbol{A}-\boldsymbol{C}, \boldsymbol{E}, \boldsymbol{F})$ or three $(\boldsymbol{D}, \boldsymbol{G})$ experiments.

These results suggest that SGCs are activated and play a role in the genesis of herpetic pain, but that this is not triggered by TNF/ TNFR1 signaling.

An important physiological role of SGCs is to control extracellular $\mathrm{K}^{+}$concentrations through the inwardly rectifying $\mathrm{K}^{+}$ channel Kir 4.1 (Tang et al., 2010). There is evidence that, during pathological pain conditions (e.g., neuropathic and inflammatory pain), a downregulation in Kir4.1 channel expression and current leads to an impairment of $\mathrm{DRG} \mathrm{K}^{+}$homeostasis, which contributes to development of pathological pain (Ohara et al., 2009). Based on this evidence, we evaluated the expression of Kir4.1 in the DRGs of mice during herpetic neuralgia. There was a time-dependent decrease in the expression of the gene that encodes for Kir4.1 (Kcnj10) in the DRGs of HSV-1-infected mice (Fig. 9A). The Kir4.1 protein expression was also reduced in the DRGs of HSV-1-infected mice (Fig. 9 $B, C$ ). Importantly, knockdown of Kir4.1 channels in SGCs by the use of ShRNA-Kir4.1 is sufficient to promote pain hypersensitivity in naive mice (Fig. $9 D, E)$. Next, we investigated whether TNF/TNFR1 signaling might be involved in the downregulation of Kir4.1 channels after
HSV-1 infection. First, it was found that TNFR1 is coexpressed with Kir4.1 channels in SGCs (Fig. 10A). Furthermore, whereas the expression of Kir4.1 (gene and protein) was reduced in the DRGs of WT infected mice, this was not observed in Tnfr1 ${ }^{-1-}$ mice (Fig. $10 B, C$ ). Finally, the incubation of primary culture of SGCs with TNF reduced Kcnj10 expression (Fig. 10D). Altogether, these results indicate for the first time that TNF modulates the expression of Kir4.1 in SGCs, which might account for the development of acute herpetic neuralgia.

\section{Discussion}

Herpetic neuralgia is the most important symptom of herpes zoster. Here, we used a murine model of HSV-1 cutaneous infection to evaluate the mechanism involved in the development of acute herpetic pain. Peripheral infection with HSV-1 leads to development of pain hypersensitivity and zosteriform-like lesions, which resemble the human herpes zoster. Furthermore, the present study shows the crucial role of the immune/inflammatory response at the sensory ganglia for the development of acute herpetic neuralgia, revealing a possible mechanism by which neu- 
A

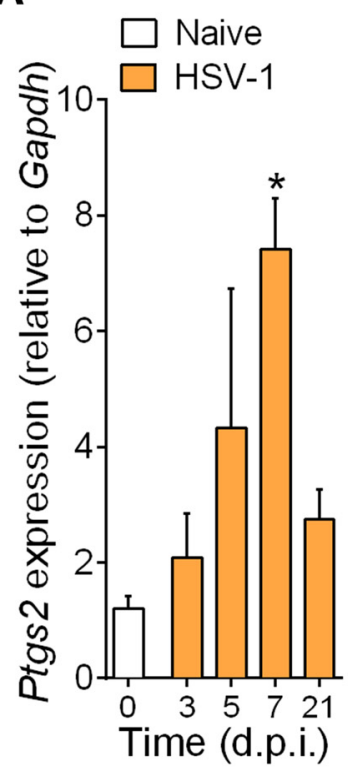

B
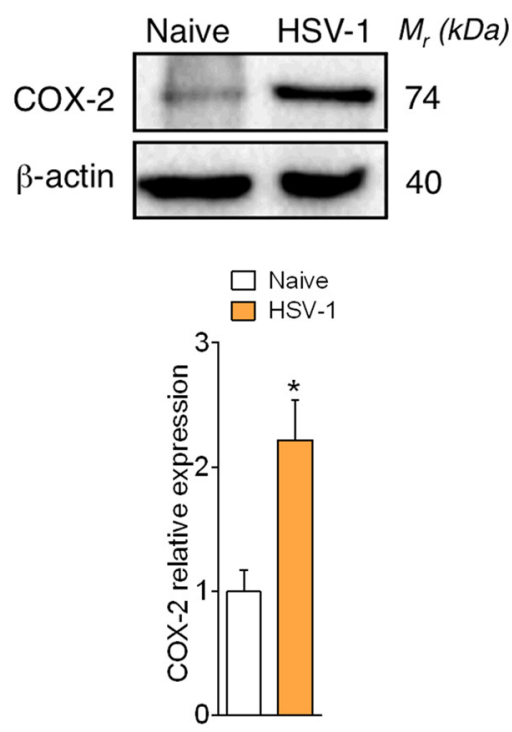

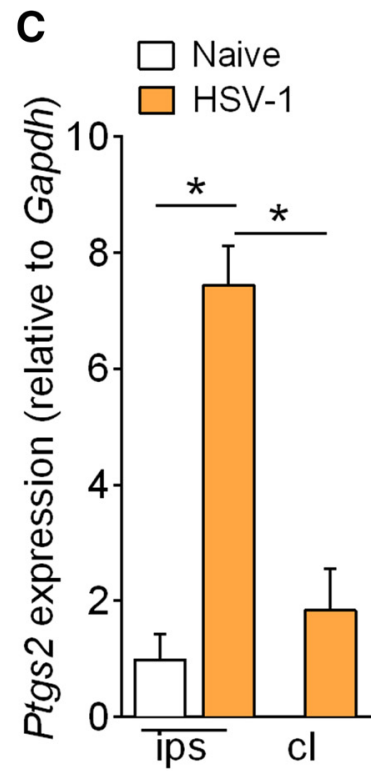

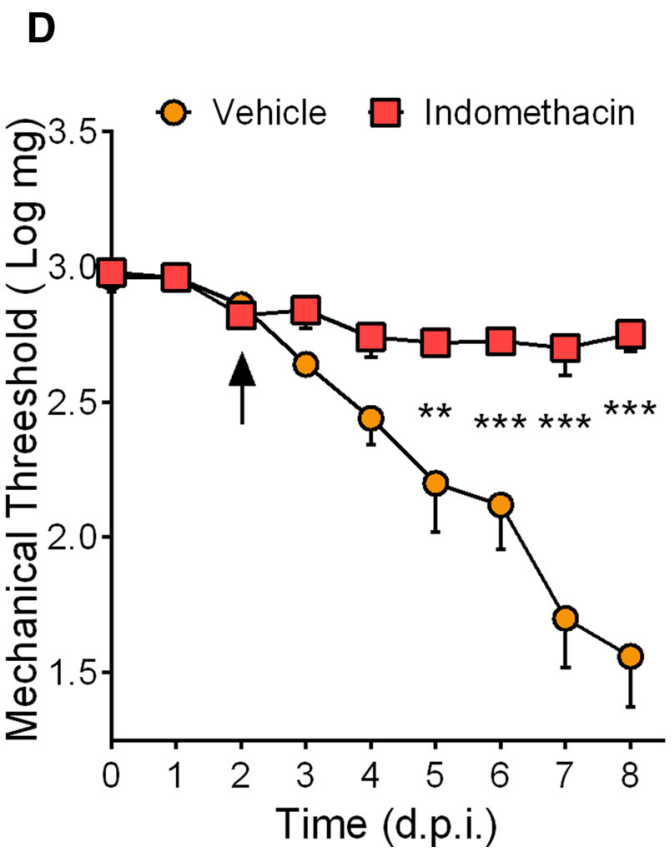

E

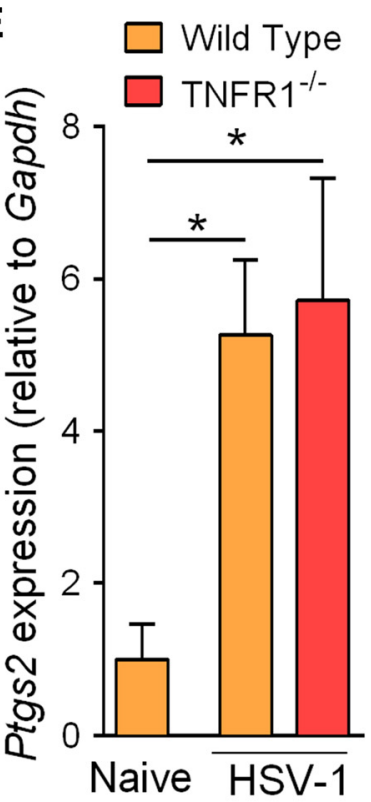

Figure 6. COX-2-derived products are involved in the genesis of herpetic neuralgia, which is not triggered by TNF. C57BL/6 mice were inoculated with HSV- $1\left(2 \times 10^{5} \mathrm{PFUs}\right)$ on the shin of the right hindpaw. A, Relative mRNA expression of Ptgs 2 in infected DRGs (L3-L6) up to $21 \mathrm{dpi}(n=7$ for each time point). $\boldsymbol{B}$, Representative and desintometric quantification of Western blotting of COX-2 protein expression in DRGs ( $n=4$ per group). C, Relative mRNA expression of Ptgs 2 in ipsilateral and contralateral DRGs (L3-L6) of infected mice and naive mice ( $n=6$ per group). $\boldsymbol{D}$, Infected mice $(n=5$ per group) were treated daily with indomethacin ( $10 \mu \mathrm{g}$ of drug in $5 \mu$ l of saline, i.t.) or saline (vehicle) from 2 to 7 dpi. Mechanical nociceptive threshold was determined at $0-7$ dpi. $\boldsymbol{E}$, Relative mRNA expression of Ptgs2 in DRGs (L3-L6) from infected WT and TNFR1 (TNFR1 ${ }^{-1-}$ ) knock-out mice at 7 dpi ( $n=6$ per group). Data are expressed as the mean \pm SEM. ${ }^{*} p<0.05$; ${ }^{* *} p<0.01 ;{ }^{* * *} p<0.001$ for differences between the differences of Ptgs $2 \mathrm{mRNA}(\boldsymbol{A}, \boldsymbol{C}, \boldsymbol{E} ;$; one-way ANOVA, Dunn's post test) or COX-2 protein expression ( $\boldsymbol{B}$; Tukey's $t$ test) in infected DRGs and the differences between the nociceptive behavior of infected treated mice compared with vehicle mice ( $\boldsymbol{D}$; two-way ANOVA, Tukey's $t$ test). Data are representative of two $(\boldsymbol{A}, \boldsymbol{D})$, three $(\boldsymbol{C}, \boldsymbol{E})$, or four $(\boldsymbol{B})$ experiments.

trophils and macrophages can modulate SGCs through TNF production.

The peripheral infection of mice with HSV-1 has been characterized previously as a model of acute herpetic pain (Takasaki et al., 2000a; Takasaki et al., 2000b; Takasaki et al., 2002). In agreement, we showed that the infection of mice leads to the development of skin zosteriform-like lesions that were accompanied by mechanical pain hypersensitivity. We also characterized that, after peripheral infection, the HSV-1 reached the sensory ganglia receiving innervation of the infected region. As a demonstration of the predictive validity of the model compared with human herpes zoster, HSV-1-induced pain hypersensitivity was transiently inhibited by NSAIDs, opioids, and local anesthetics.

The neuroimmune-glia process across the nociceptive system (sensory ganglia and spinal cord) has been implicated in the genesis of several types of pathological pain, including inflammatory and neuropathic pain (Austin and Moalem-Taylor, 2010). Here, we found that the development of herpetic neuralgia is also me- 
A

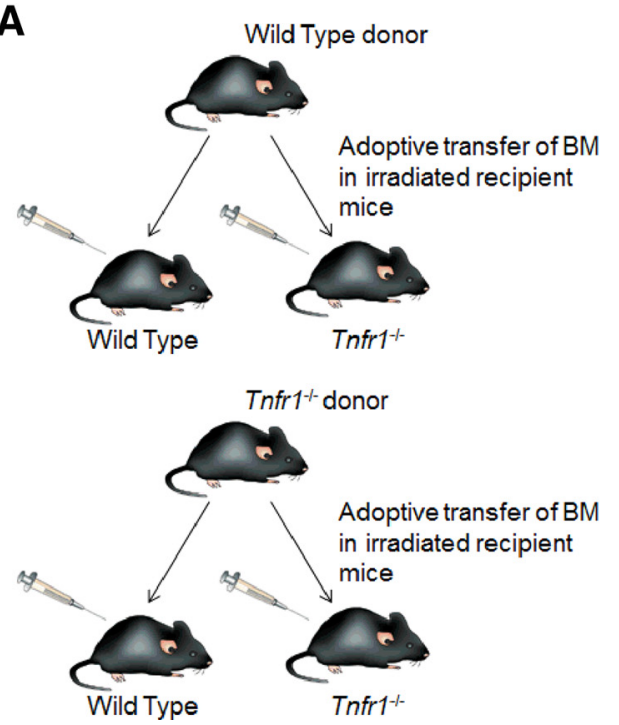

B

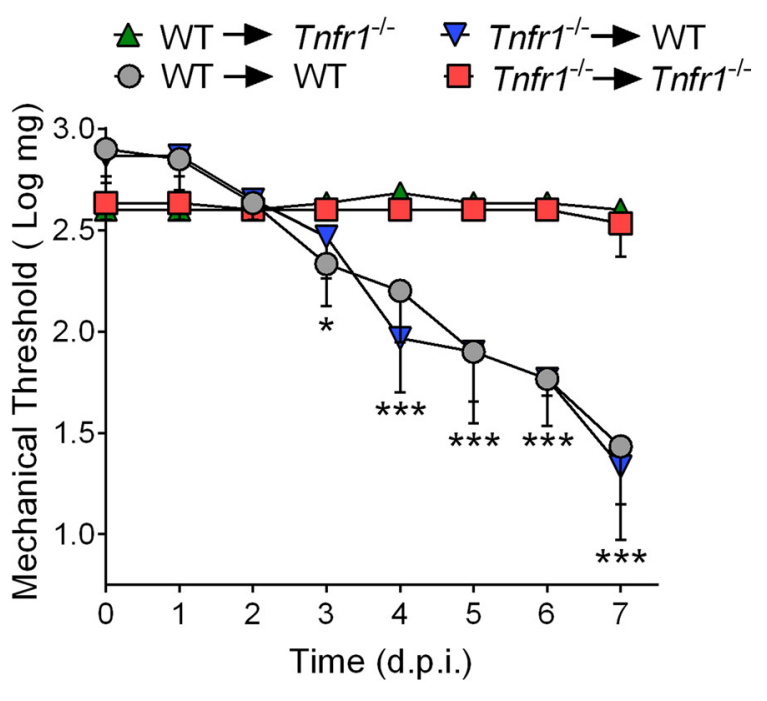

Figure 7. TNF- $\alpha$ /TNR1 signaling in nonhematopoietic cells accounts for the development of acute herpetic neuralgia. $\boldsymbol{A}$, Representative scheme of chimeric mice establishment using TNFR $^{-1-}$ and WT mice. $B$, Chimeric mice were inoculated with HSV-1 $\left(2 \times 10^{5}\right.$ PFUs) on the shin of the right hindpaw. Mechanical nociceptive thresholds of chimeric infected mice ( $n=10$ per group) were measured from 0 to $7 \mathrm{dpi}$. Data are expressed as the mean \pm SEM. ${ }^{*} p<0.05 ;{ }^{* * *} p<0.001$ for the differences between the nociceptive behavior of infected mice (two-way ANOVA).

A

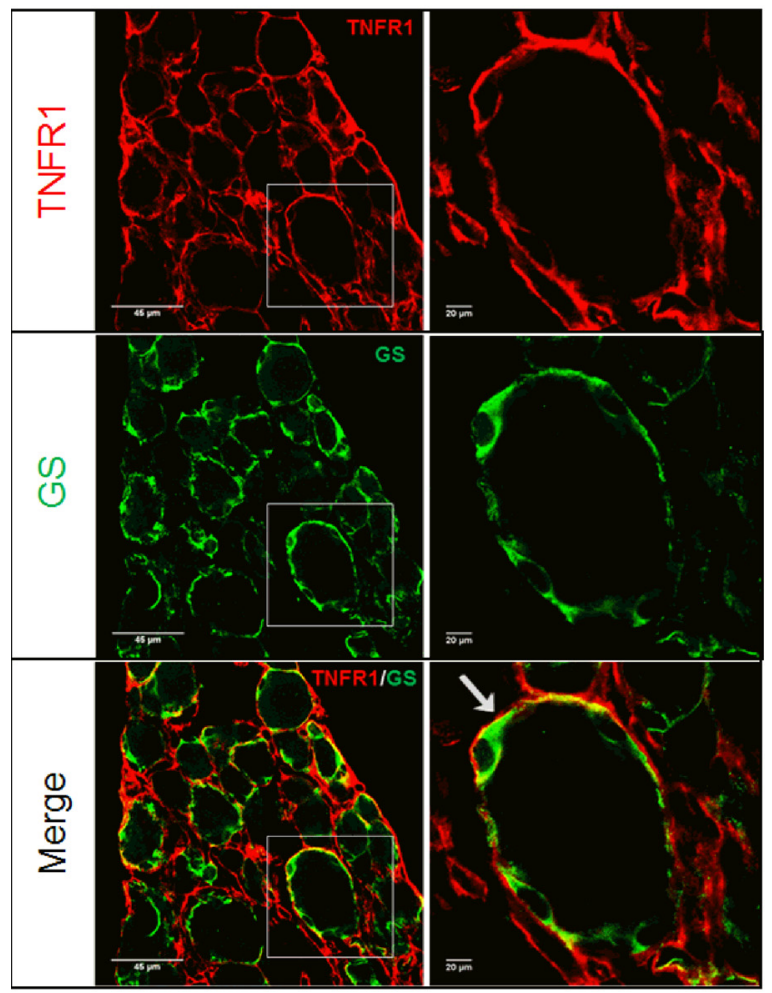

B

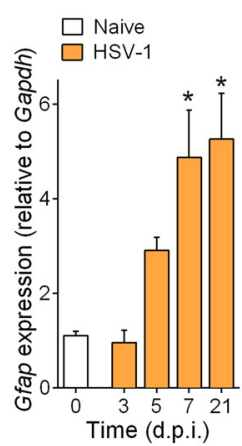

E

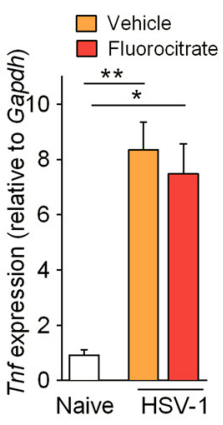

C
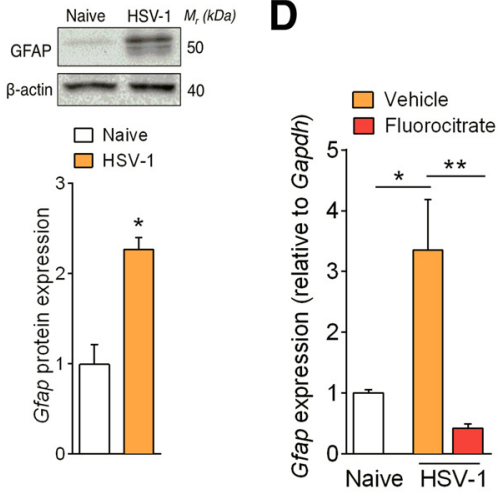

F

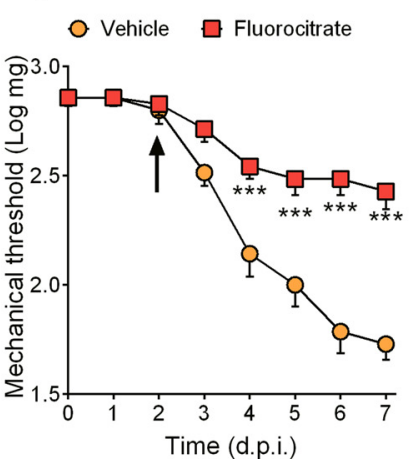

G

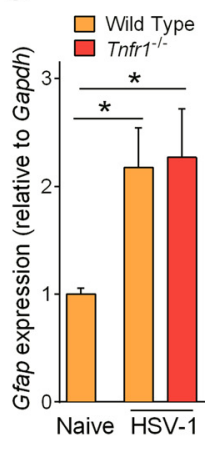

Figure 8. TNF- $\alpha /$ TNR1 signaling is not involved in SGC activation. $\boldsymbol{A}$, Representative imunofluorescence for GS and TNFR1 immunoreactivity in DRG slices from naive mice. $\boldsymbol{B}$, C57BL/6 mice were inoculated with HSV-1 ( $2 \times 10^{5}$ PFUs) on the shin of the right hindpaw. Relative mRNA expression of Gfap in infected DRGs (L3-L6) at $0,3,5$, and $7 \mathrm{dpi}(n=6$ for each time point). C, Representative and densitometric quantification of Western blotting of GFAP protein expression in DRGS ( $n=4$ per group). $\boldsymbol{D}, \boldsymbol{E}$, Infected mice ( $n=5$ per group) were treated daily with fluorocitrate $(0.03 \mathrm{nmol}$, i.t.) or saline (vehicle) from 2 to $7 \mathrm{dpi}$ followed by the quantification of $G f a p(\boldsymbol{D})$ and $\operatorname{Tnf}(\boldsymbol{E}) \mathrm{mRNA}$ expression. $\boldsymbol{F}$, Mechanical nociceptive threshold was determined in infected mice treated daily with fluorocitrate. The arrow indicates the beginning of treatment. G, Relative mRNA expression of Gfap in DRGs (L3-L6) from infected WT and Infr $1^{-1-}$ mice ( $n=6$ per group) at 7 dpi. Data are expressed as the mean \pm SEM. ${ }^{*} p<0.05 ;{ }^{* *} p<0.01 ;{ }^{* * *} p<0.001$ differences between the nociceptive behavior of infected mice (two-way ANOVA, Bonferroni's post test) and for differences of Gfap or Tnf mRNA expression ( $\boldsymbol{B}, \boldsymbol{D}, \boldsymbol{E}, \mathbf{G}$; one-way ANOVA, Tukey's post test). Data are representative of two (A, $\boldsymbol{B}, \boldsymbol{D}, \boldsymbol{E}$, $\boldsymbol{F})$, three $(\boldsymbol{G})$, or four $(\boldsymbol{C})$ experiments. 
A
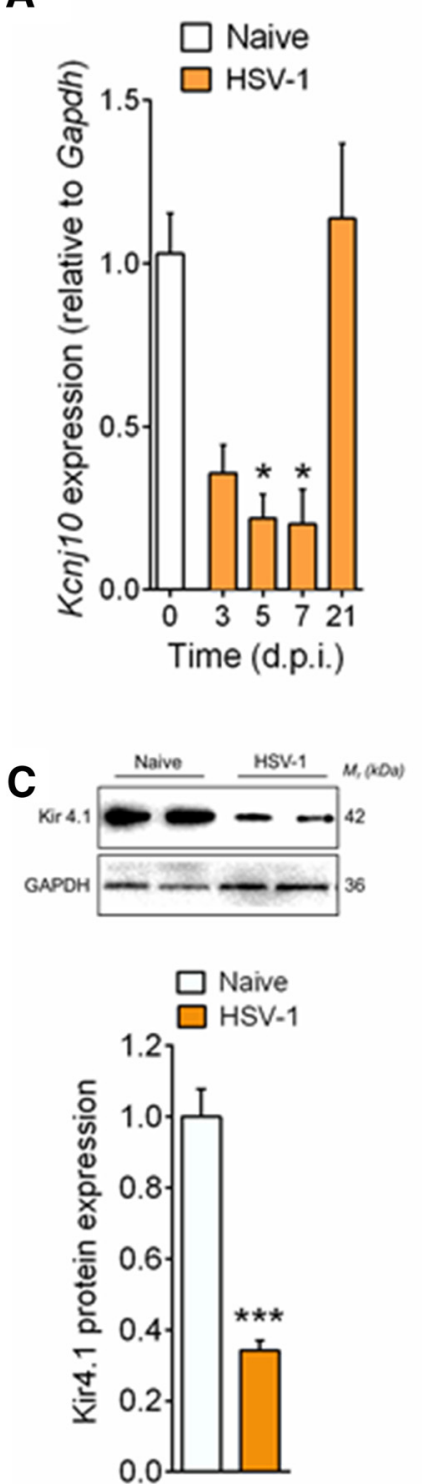

B

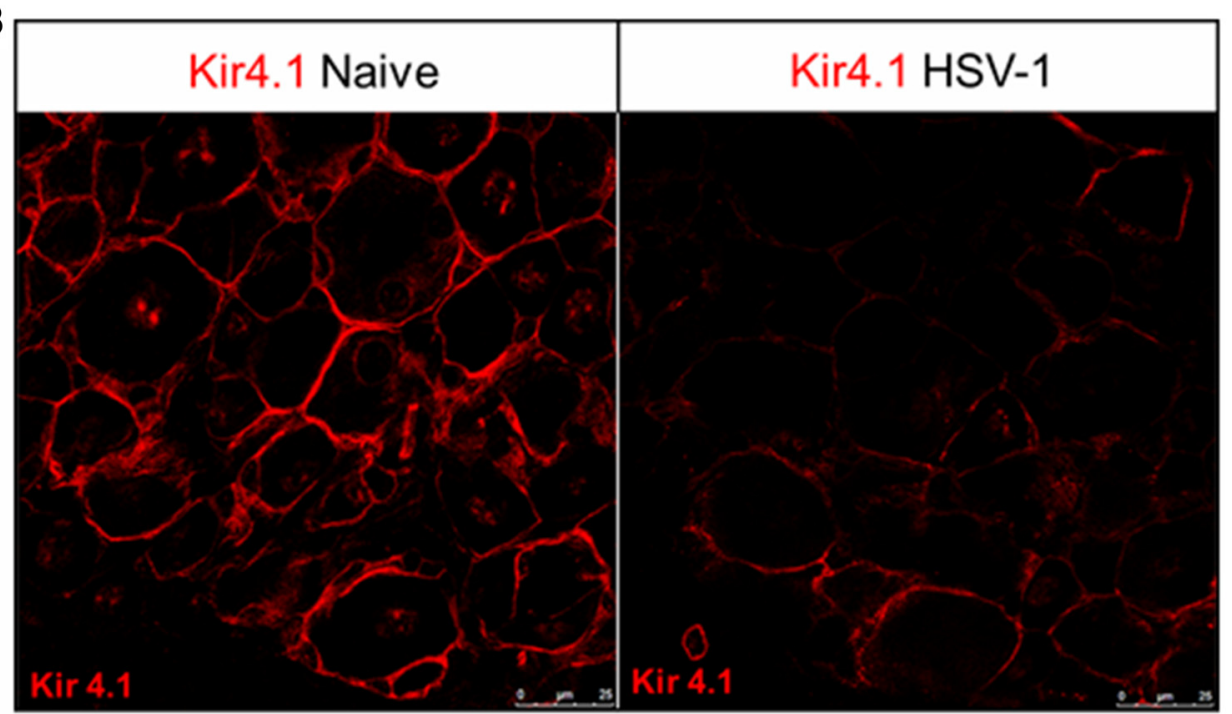

E

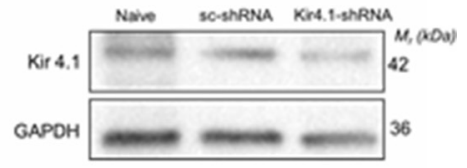

O Naive $\square$ sc-shRNA $\triangle$ Kir4.1-shRNA
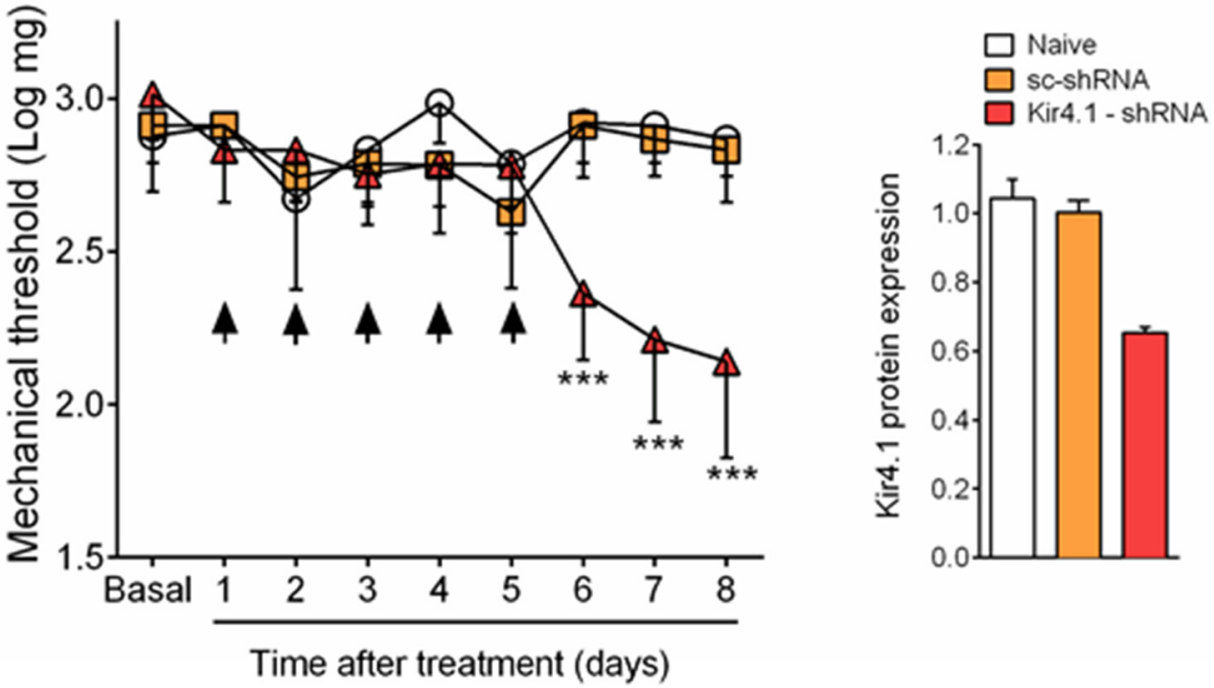

Figure 9. Kir4.1 expression in SGCs is downregulated during acute herpetic neuralgia. $\boldsymbol{A}$, Relative mRNA expression of Kcnj10 in infected DRGs (L3-L6) up to $21 \mathrm{dpi}(n=7$ for each time point). $\boldsymbol{B}$, Representative immunofluorescence for Kir4.1 immunoreactivity in DRGs slices from naive and HSV-1-infected mice (7 dpi). $\boldsymbol{C}$, Representative and densitometric quantification of Western blotting of Kir4.1 protein expression in DRGs ( $n=4$ per group) from naive and HSV-1-infected mice (7 dpi). D, Naive mice ( $n=5$ per group) were treated daily with ShRNA-Kir4.1 or ShRNA-control for 5 consecutive days (indicated arrows). The mechanical nociceptive threshold was determined 0 to 8 after treatment. $\boldsymbol{E}$, Representative and desintometric quantification of Western blotting of Kir 4.1 protein expression in DRGs ( $n=5$ per group) from naive or ShRNA treated mice Data are expressed as the mean \pm SEM. ${ }^{*} p<0.05$; ${ }^{* *} p<0.01$; ${ }^{* * *} p<0.001$ differences between the nociceptive behavior of infected mice ( $\boldsymbol{D}$; two-way ANOVA, Bonferroni's post test) and for differences of Kcnj10 mRNA ( $\boldsymbol{A}$; one-way ANOVA, Tukey's post test) or Kir4.1 protein expression ( $\boldsymbol{C}$, $\boldsymbol{E}$; one-way ANOVA, Tukey's post test). Data are representative of one $(\boldsymbol{D}, \boldsymbol{E})$ or two $(\boldsymbol{A}-\boldsymbol{C})$ experiments.

diated by neuroimmune-glia interactions in the sensory ganglia. For instance, after peripheral infection with HSV-1, the virus reaches the sensory ganglion, leading to a local immune/inflammatory response. The main characteristic of the immune response in the sensory ganglia associated with the temporal development of acute herpetic neuralgia is the infiltration of macrophage and neutrophils and few cells from the adaptive immunity. In agreement, after HSV-1 ocular infection, the migration of neutrophils and macrophages to trigeminal ganglia occurs during the acute phase, whereas the presence of lymphocytes $(\mathrm{CD} 4+$ and $\mathrm{CD} 8+)$ is only detected at late stages (Shimeld et al.,
1995). Interestingly, these cells are not able to infiltrate the spinal cord after peripheral infection with HSV-1. Because inhibition of leukocyte infiltration or depletion of neutrophils and macrophages reduced HSV-1-induced pain hypersensitivity, the sensory ganglia is the most affected site of the nociceptive system responsible for the development of acute herpetic neuralgia.

One remaining point in our model is regarding the mechanism involved in the initiation of the immune response in the sensory ganglion. This initial response might be triggered via the recognition of the virus by infected and noninfected cells through 
A

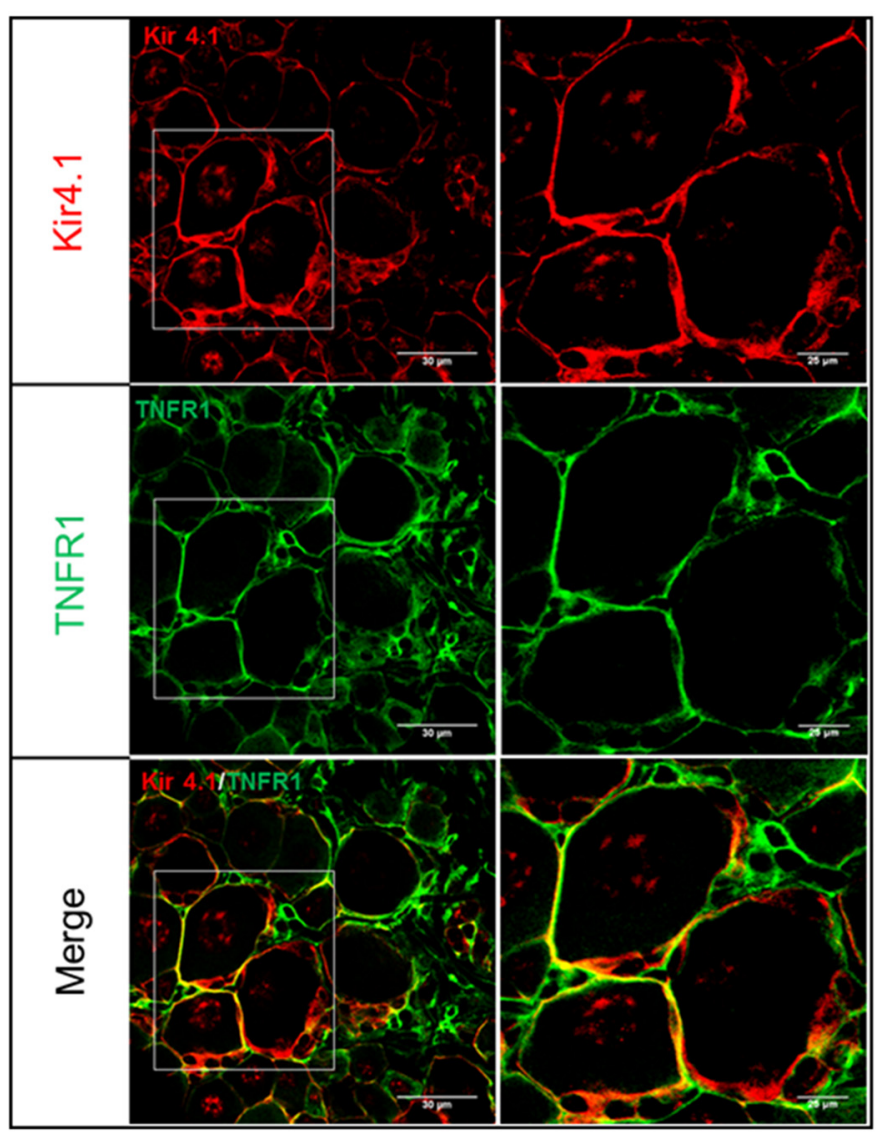

B

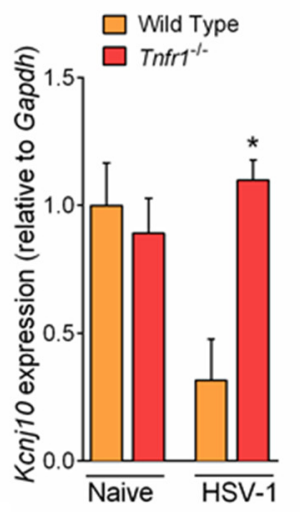

D

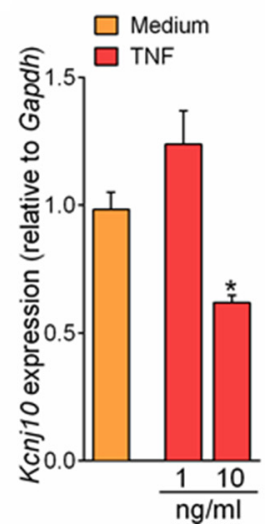

C

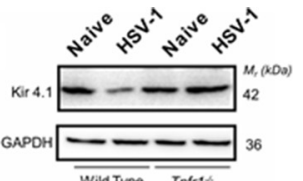

Wild Type Intrit

$\square$ Wild Type

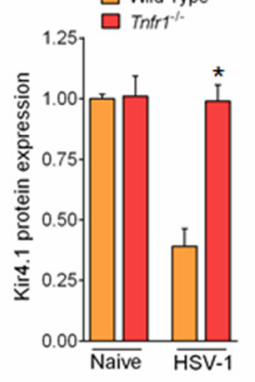

Figure 10. TNF/TNR1 signaling downmodulates the expression of Kir4.1 in SGCS, which might account for herpetic neuralgia. $A$, Representative imunofluorescence for Kir4.1 and TNFR1 immunoreactivity in DRGs slices from naive mice. $\boldsymbol{B}$, Relative mRNA expression of Kcnj10 in DRGs (L3-L6) from infected WT and Tnfr ${ }^{-1-}$ mice $(n=6$ per group) at 7 dpi. C, Representative and densitometric quantification of Western blotting of Kir4.1 protein expression in DRGs ( $n=4$ per group) from WT and $I n f r 1^{-1-}$ mice infected with HSV-1 (7 dpi). D, Relative mRNA expression of $K c n j 10$ in culture of mice SGCs after stimulation with recombinant TNF. Data are expressed as the mean \pm SEM. ${ }^{*} p<0.05 ;{ }^{* *} p<0.01 ;{ }^{* * *} p<0.001$ for differences of $K c n j 10$ mRNA expression $(\boldsymbol{B}, \boldsymbol{D}$; one-way ANOVA, Tukey's post test) or Kir4.1 expression (C). Data are representative of two (A-D) experiments.

pattern recognition receptors (PRRs). There is evidence that tolllike receptors (TLRs) are involved in HSV-1 recognition (Paludan et al., 2011). Furthermore, diverse ganglia components such as sensory neurons, macrophages, and Schwann cells express TLRs, including TLR2, TLR4, TLR7, and TLR9 (Okun et al., 2011). The genetic impairment of TLRs influences the outcome of HSV-1 infection, suggesting that the virus or its byproducts are capable of activating these receptors (Kurt-Jones et al., 2004; Sarangi et al., 2007; Lima et al., 2010; Lafaille et al., 2012). Therefore, HSV-1 recognition via PRRs might promote an immune response in the sensory ganglia, resulting in leukocyte infiltration and production of inflammatory mediators.

The possible role of sensory-ganglia-infiltrating leukocytes in acute herpetic pain might be through the production of inflammatory mediators (Kodukula et al., 1999; Rittner and Brack, 2007). In fact, neutrophils and macrophages infiltrating the nerves and sensory ganglia after nerve injury are capable of producing algesic mediators (Witko-Sarsat et al., 2000; Verri et al., 2006; Cunha et al., 2008; Shaw et al., 2008). Among the most important pronociceptive mediators related to pain conditions, the present study revealed the essential role of TNF/TNFR1 signaling for the development of acute herpetic neuralgia, which is triggered by the infiltrated leukocytes. Corroborating this, the upregulation of TNF in infected DRGs coincided with the temporal pattern of leukocyte infiltration and pain hypersensitivity.
The local inhibition of this cytokine resulted in a reduction of pain behavior. Moreover, Tnfr $1^{-1-}$ mice did not show pain behavior in the course of HSV-1 infection.

In addition to demonstrating the participation of TNF in the genesis of herpetic pain, we also addressed the mechanism by which TNF mediates this type of pain. Although TNF is very important for leukocyte migration in several models of inflammation and inflammatory diseases, it was not involved in leukocyte recruitment into sensory ganglia after HSV-1 infection. Therefore, other cytokines/chemokines are involved in the recruitment of leukocyte to sensory ganglia in the absence of TNF. In this context, neuronal infection by different virus triggers chemokine production to initiate an inflammatory response against these pathogens in the nervous system (Patterson et al., 2003; Klein et al., 2005; Hicks et al., 2013). Moreover, in ocular HSV-1 infection, CCL2, CCL5, CXCL9, and CXCL10 are upregulated in the trigeminal ganglia $72 \mathrm{~h}$ after infection, coinciding with the time point when the virus reaches this tissue (Carr et al., 2006).

The present results also revealed that TNF/TNFR1 signaling that account for acute herpetic pain probably occurs in intrinsic cells of the DRGs; the main possibilities would be on SGCs or directly on primary sensory neurons. There is evidence that TNF acting on SGCs participates in the genesis of inflammatory and neuropathic pain (Vit et al., 2008; Ohara et al., 2009; Takeda et al., 
2011). Herein, it was shown that TNFR1 in sensory ganglia is mainly expressed in SGCs. However, the mechanisms by which TNF/TNFR1 signaling modulates SGCs functions have not been addressed. Unexpectedly, Tnfr1 ${ }^{-1-}$ mice did not exhibit a reduced activation of SGCs (similar GFAP expression compared with WT mice) after HSV-1 infection.

One important mechanism by which SGCs contribute to the maintenance of pathological pain is related to the downregulation of Kir4.1 expression. In the sensory ganglia, this channel is expressed exclusively in SGCs. It is responsible for $\mathrm{K}^{+}$buffering and can influence the level of neuronal excitability indirectly, which in turn has been associated with inflammatory and neuropathic pain conditions (Vit et al., 2006). Indeed, knock-down of Kir4.1 expression in trigeminal ganglia enhances primary sensory neurons excitability, leading to spontaneous and evoked pain-like behavior. In addition, the Kir4.1 expression in the trigeminal ganglion is reduced after chronic constriction injury of the infraorbital nerve (Vit et al., 2008). Furthermore, peripheral inflammation reduces Kir4.1 expression in trigeminal SGCs, increasing extracellular $\mathrm{K}^{+}$concentrations (Takeda et al., 2011). The present study is the first to demonstrate that TNF, acting directly in SGCexpressing TNFR1, mediates this process in pain conditions. Therefore, it is plausible to suggest that therapies enhancing Kir4.1 channels current in SGCs, such as GABAB receptor agonists, may be useful for the treatment of acute herpetic pain (Takeda et al., 2015). In addition to the modulation of Kir4.1 expression on SGCs, we could not exclude that a direct action of TNF in the cell body of primary nociceptive neurons might mediate the genesis of herpetic pain. For instance, there are studies showing that TNF is able to sensitize directly the primary sensory nociceptive neurons in vitro (Ohtori et al., 2004; Dubový et al., 2006; Schäfers et al., 2008; Jancálek et al., 2010). TNFR1 is also upregulated in sensory neurons in models of neuropathic and inflammatory pain (Ohtori et al., 2004; Inglis et al., 2005; Dubový et al., 2006; Jancálek et al., 2010). The generation of specific TNFR1-deficient conditional mice in primary sensory neurons will unravel this issue.

The discovery of the role of TNF in acute herpetic pain also creates perspectives of novel treatments. Currently, steroidal anti-inflammatory drugs such as prednisone are widely used for alleviation of herpetic pain (Santee, 2002; Cohen, 2013). However, the mechanism of action of these drugs in herpes zoster is unknown and might be related to the reduction of leukocyte migration to ganglia. However, regarding viral replication, the consequences of this reduction are unknown because these cells are essential for control of the infection. A much safer approach, in this case, would be the employment of TNF inhibitors associated with antiviral drugs for herpes zoster neuralgia.

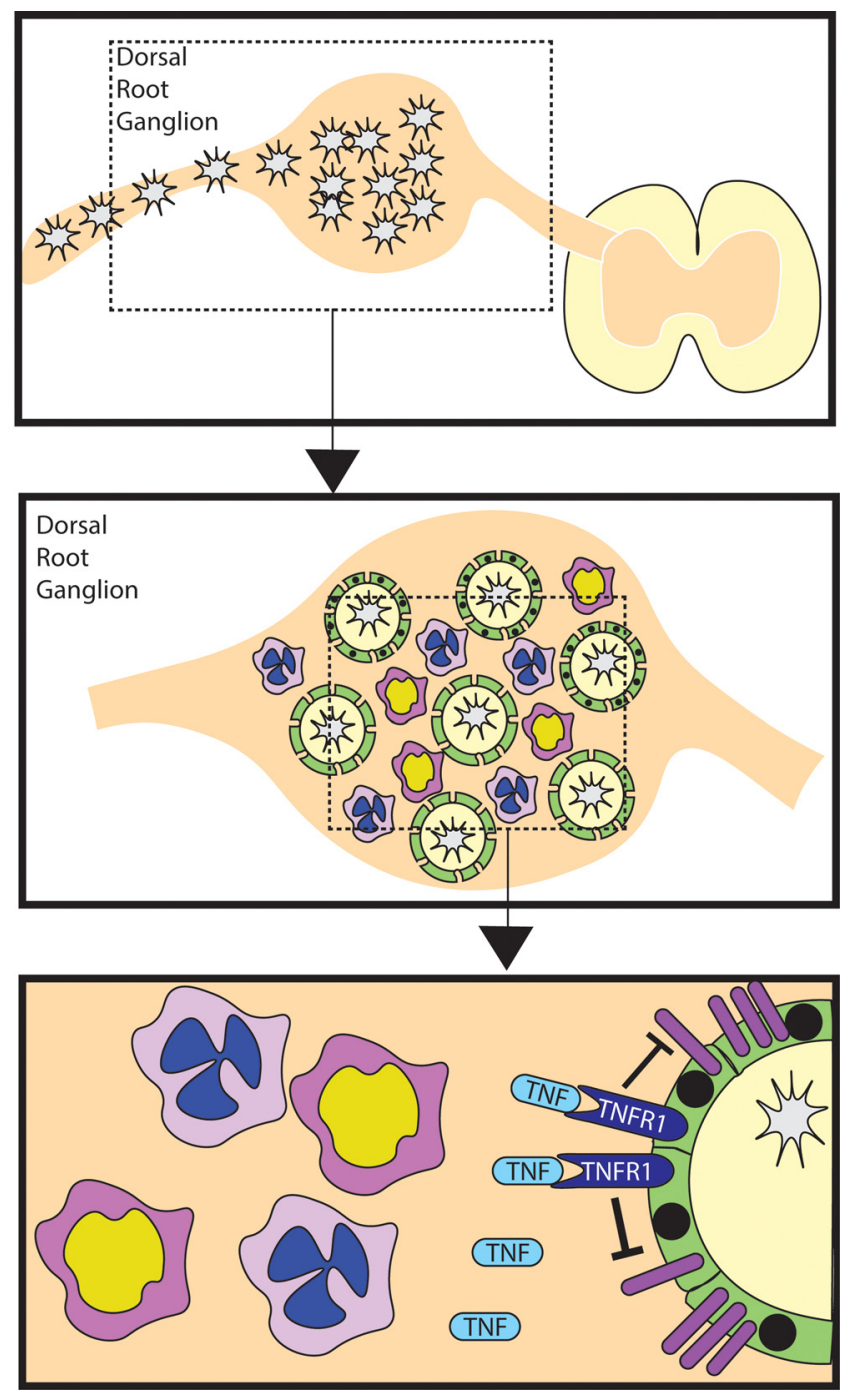

Figure 11. Schematic representation of neuroimmune interactions occurring at the sensory ganglia that account for the development of acute herpetic neuralgia. HSV-1 replicates in the sensory ganglia that leads to the induction of a local ary/immune response. It is characterized by the infiltration of leukocytes (mainly macrophages and neutrophils) which contributes indirectly to enhance primary sensory neurons excitability and finally to the development of herpetic

treatment. In addition, this approach might be beneficial to preventing the development of postherpetic neuralgia (PHN). For instance, a lower incidence of PHN is observed in patients under treatment with anti-TNF drugs (Javed et al., 2011). Therefore, in addition to its role in acute herpetic pain, TNF might also be involved in the development of PHN and its inhibition in the acute phase would be beneficial for PHN prevention.

In summary, the present data demonstrate the essential role of sensory ganglia neuroinflammation (leukocyte recruitment and the production of TNF) for the genesis of acute herpetic neuralgia. Furthermore, they indicate that TNF/TNFR1 signaling in SGCs mediates the development of herpetic neuralgia through the downregulation of Kir4.1 expression. The neuroimmuneglia interaction mechanisms described in the present study that account for the development of acute herpetic neuralgia are depicted in Figure 11. In conclusion, the present study elucidates novel cellular and molecular mechanisms involved in the genesis of acute herpetic neuralgia and open new avenues for its control. 


\section{References}

Austin PJ, Moalem-Taylor G (2010) The neuroimmune balance in neuropathic pain: involvement of inflammatory immune cells, immune-like glial cells and cytokines. J Neuroimmunol 229:26-50. CrossRef Medline

Belzer V, Shraer N, Hanani M (2010) Phenotypic changes in satellite glial cells in cultured trigeminal ganglia. Neuron Glia Biol 6:237-243. CrossRef Medline

Carr DJ, Ash J, Lane TE, Kuziel WA (2006) Abnormal immune response of CCR5-deficient mice to ocular infection with herpes simplex virus type 1 . J Gen Virol 87:489-499. CrossRef Medline

Cohen JI (2013) Clinical practice: herpes zoster. N Engl J Med 369:255-263. CrossRef Medline

Colleoni M, Sacerdote P (2010) Murine models of human neuropathic pain. Biochim Biophys Acta 1802:924-933. CrossRef Medline

Cunha TM, Verri WA Jr, Vivancos GG, Moreira IF, Reis S, Parada CA, Cunha FQ, Ferreira SH (2004) An electronic pressure-meter nociception paw test for mice. Braz J Med Biol Res 37:401-407. CrossRef Medline

Cunha TM, Verri WA Jr, Schivo IR, Napimoga MH, Parada CA, Poole S, Teixeira MM, Ferreira SH, Cunha FQ (2008) Crucial role of neutrophils in the development of mechanical inflammatory hypernociception. J Leukoc Biol 83:824-832. CrossRef Medline

Daley JM, Thomay AA, Connolly MD, Reichner JS, Albina JE (2008) Use of Ly6G-specific monoclonal antibody to deplete neutrophils in mice. J Leukoc Biol 83:64-70. Medline

Dubový P, Jancálek R, Klusáková I, Svízenská I, Pejchalová K (2006) Intraand extraneuronal changes of immunofluorescence staining for TNFalpha and TNFR1 in the dorsal root ganglia of rat peripheral neuropathic pain models. Cell Mol Neurobiol 26:1205-1217. Medline

Faust N, Varas F, Kelly LM, Heck S, Graf T (2000) Insertion of enhanced green fluorescent protein into the lysozyme gene creates mice with green fluorescent granulocytes and macrophages. Blood 96:719-726. Medline

Freland S, Ljunggren HG (2000) Beta 2-microglobulin/CD8 -/- mice reveal significant role for $\mathrm{CD} 8+\mathrm{T}$ cells in graft rejection responses in beta 2-microglobulin -/- mice. Scand J Immunol 51:219-223. CrossRef Medline

Gan EY, Tian EA, Tey HL (2013) Management of herpes zoster and postherpetic neuralgia. Am J Clin Dermatol 14:77-85. CrossRef Medline

Gilden D, Mahalingam R, Nagel MA, Pugazhenthi S, Cohrs RJ (2011) Review: the neurobiology of Varicella zoster virus infection. Neuropathol Appl Neurobiol 37:441-463. CrossRef Medline

Hicks DJ, Núñez A, Banyard AC, Williams A, Ortiz-Pelaez A, Fooks AR, Johnson N (2013) Differential chemokine responses in the murine brain following lyssavirus infection. J Comp Pathol 149:446-462. CrossRef Medline

Inglis JJ, Nissim A, Lees DM, Hunt SP, Chernajovsky Y, Kidd BL (2005) The differential contribution of tumour necrosis factor to thermal and mechanical hyperalgesia during chronic inflammation. Arthritis Res Ther 7:R807-R816. CrossRef Medline

Jancálek R, Dubový P, Svízenská I, Klusáková I (2010) Bilateral changes of TNF-alpha and IL-10 protein in the lumbar and cervical dorsal root ganglia following a unilateral chronic constriction injury of the sciatic nerve. J Neuroinflammation 7:11. CrossRef Medline

Javed S, Kamili QU, Mendoza N, Tyring SK (2011) Possible association of lower rate of postherpetic neuralgia in patients on anti-tumor necrosis factor-alpha. J Med Virol 83:2051-2055. CrossRef Medline

Klein RS, Lin E, Zhang B, Luster AD, Tollett J, Samuel MA, Engle M, Diamond MS (2005) Neuronal CXCL10 directs CD8 + T-cell recruitment and control of West Nile virus encephalitis. J Virol 79:11457-11466. CrossRef Medline

Kodukula P, Liu T, Rooijen NV, Jager MJ, Hendricks RL (1999) Macrophage control of herpes simplex virus type 1 replication in the peripheral nervous system. J Immunol 162:2895-2905. Medline

Kurt-Jones EA, Chan M, Zhou S, Wang J, Reed G, Bronson R, Arnold MM, Knipe DM, Finberg RW (2004) Herpes simplex virus 1 interaction with Toll-like receptor 2 contributes to lethal encephalitis. Proc Natl Acad Sci U S A 101:1315-1320. CrossRef Medline

Lafaille FG et al. (2012) Impaired intrinsic immunity to HSV-1 in human iPSC-derived TLR3-deficient CNS cells. Nature 491:769-773. CrossRef Medline

Lima GK, Zolini GP, Mansur DS, Freire Lima BH, Wischhoff U, Astigarraga RG, Dias MF, das Graças Almeida Silva M, ${ }^{*}$ Béla SR, do Valle Antonelli LR, Arantes RM, Gazzinelli RT, Báfica A, Kroon EG, Campos MA (2010) Toll-like receptor (TLR) 2 and TLR9 expressed in trigeminal ganglia are critical to viral control during herpes simplex virus 1 infection. Am J Pathol 177:2433-2445. CrossRef Medline

Madsen L, Labrecque N, Engberg J, Dierich A, Svejgaard A, Benoist C, Mathis D, Fugger L (1999) Mice lacking all conventional MHC class II genes. Proc Natl Acad Sci U S A 96:10338-10343. CrossRef Medline

Mestre C, Pélissier T, Fialip J, Wilcox G, Eschalier A (1994) A method to perform direct transcutaneous intrathecal injection in rats. J Pharmacol Toxicol Methods 32:197-200. CrossRef Medline

Nagel MA, Gilden D (2014) Neurological complications of Varicella zoster virus reactivation. Curr Opin Neurol 27:356-360. CrossRef Medline

Njoo C, Heinl C, Kuner R (2014) In vivo SiRNA transfection and gene knock-down in spinal cord via rapid noninvasive lumbar intrathecal injections in mice. J Vis Exp: 85. CrossRef Medline

O'Connor KM, Paauw DS (2013) Herpes zoster. Med Clin North Am 97: 503-522, ix. CrossRef Medline

Ohara PT, Vit JP, Bhargava A, Romero M, Sundberg C, Charles AC, Jasmin L (2009) Gliopathic pain: when satellite glial cells go bad. Neuroscientist 15:450-463. CrossRef Medline

Ohtori S, Takahashi K, Moriya H, Myers RR (2004) TNF-alpha and TNFalpha receptor type 1 upregulation in glia and neurons after peripheral nerve injury: studies in murine DRG and spinal cord. Spine 29:10821088. CrossRef Medline

Okun E, Griffioen KJ, Mattson MP (2011) Toll-like receptor signaling in neural plasticity and disease. Trends Neurosci 34:269-281. CrossRef Medline

Opstelten W, McElhaney J, Weinberger B, Oaklander AL, Johnson RW (2010) The impact of Varicella zoster virus: chronic pain. J Clin Virol 48:S8-S13. CrossRef Medline

Paludan SR, Bowie AG, Horan KA, Fitzgerald KA (2011) Recognition of herpesviruses by the innate immune system. Nat Rev Immunol 11:143154. CrossRef Medline

Patterson CE, Daley JK, Echols LA, Lane TE, Rall GF (2003) Measles virus infection induces chemokine synthesis by neurons. J Immunol 171:31023109. CrossRef Medline

Rittner HL, Brack A (2007) Leukocytes as mediators of pain and analgesia. Curr Rheumatol Rep 9:503-510. CrossRef Medline

Santee JA (2002) Corticosteroids for herpes zoster: what do they accomplish? Am J Clin Dermatol 3:517-524. CrossRef Medline

Sarangi PP, Kim B, Kurt-Jones E, Rouse BT (2007) Innate recognition network driving herpes simplex virus-induced corneal immunopathology: role of the toll pathway in early inflammatory events in stromal keratitis. J Virol 81:11128-11138. CrossRef Medline

Schäfers M, Sorkin LS, Geis C, Shubayev VI (2003) Spinal nerve ligation induces transient upregulation of tumor necrosis factor receptors 1 and 2 in injured and adjacent uninjured dorsal root ganglia in the rat. Neurosci Lett 347:179-182. CrossRef Medline

Schäfers M, Sommer C, Geis C, Hagenacker T, Vandenabeele P, Sorkin LS (2008) Selective stimulation of either tumor necrosis factor receptor differentially induces pain behavior in vivo and ectopic activity in sensory neurons in vitro. Neuroscience 157:414-423. CrossRef Medline

Shaw SK, Owolabi SA, Bagley J, Morin N, Cheng E, LeBlanc BW, Kim M, Harty P, Waxman SG, Saab CY (2008) Activated polymorphonuclear cells promote injury and excitability of dorsal root ganglia neurons. Exp Neurol 210:286-294. CrossRef Medline

Shimeld C, Whiteland JL, Nicholls SM, Grinfeld E, Easty DL, Gao H, Hill TJ (1995) Immune cell infiltration and persistence in the mouse trigeminal ganglion after infection of the cornea with herpes simplex virus type 1 . J Neuroimmunol 61:7-16. CrossRef Medline

Stirling DP, Liu S, Kubes P, Yong VW (2009) Depletion of Ly6G/Gr-1 leukocytes after spinal cord injury in mice alters wound healing and worsens neurological outcome. J Neurosci 29:753-764. CrossRef Medline

Takasaki I, Andoh T, Shiraki K, Kuraishi Y (2000a) Allodynia and hyperalgesia induced by herpes simplex virus type- 1 infection in mice. Pain 86 : 95-101. CrossRef Medline

Takasaki I, Andoh T, Nitta M, Takahata H, Nemoto H, Shiraki K, Nojima H, Kuraishi Y (2000b) Pharmacological and immunohistochemical characterization of a mouse model of acute herpetic pain. Jpn J Pharmacol 83:319-326. CrossRef Medline

Takasaki I, Sasaki A, Andoh T, Nojima H, Shiraki K, Kuraishi Y (2002) Effects of analgesics on delayed postherpetic pain in mice. Anesthesiology 96:1168-1174. CrossRef Medline

Takasaki I, Nojima H, Shiraki K, Sugimoto Y, Ichikawa A, Ushikubi F, Naru- 
miya S, Kuraishi Y (2005) Involvement of cyclooxygenase-2 and EP3 prostaglandin receptor in acute herpetic but not postherpetic pain in mice. Neuropharmacology 49:283-292. Medline

Takeda M, Takahashi M, Nasu M, Matsumoto S (2011) Peripheral inflammation suppresses inward rectifying potassium currents of satellite glial cells in the trigeminal ganglia. Pain 152:2147-2156. CrossRef Medline

Takeda M, Nasu M, Kanazawa T, Shimazu Y (2015) Activation of GABA(B) receptors potentiates inward rectifying potassium currents in satellite glial cells from rat trigeminal ganglia: in vivo patch-clamp analysis. Neuroscience 288:51-58. CrossRef Medline

Tang X, Schmidt TM, Perez-Leighton CE, Kofuji P (2010) Inwardly rectifying potassium channel Kir4.1 is responsible for the native inward potassium conductance of satellite glial cells in sensory ganglia. Neuroscience 166:397-407. CrossRef Medline

Tyring SK (2007) Management of herpes zoster and postherpetic neuralgia. J Am Acad Dermatol 57:S136-S142. CrossRef Medline

van Rooijen N, Hendrikx E (2010) Liposomes for specific depletion of mac- rophages from organs and tissues. Methods Mol Biol 605:189-203. CrossRef Medline

Verri WA Jr, Cunha TM, Parada CA, Poole S, Cunha FQ, Ferreira SH (2006) Hypernociceptive role of cytokines and chemokines: targets for analgesic drug development? Pharmacol Ther 112:116-138. CrossRef Medline

Vit JP, Jasmin L, Bhargava A, Ohara PT (2006) Satellite glial cells in the trigeminal ganglion as a determinant of orofacial neuropathic pain. Neuron Glia Biol 2:247-257. CrossRef Medline

Vit JP, Ohara PT, Bhargava A, Kelley K, Jasmin L (2008) Silencing the Kir4.1 potassium channel subunit in satellite glial cells of the rat trigeminal ganglion results in pain-like behavior in the absence of nerve injury. J Neurosci 28:4161-4171. CrossRef Medline

Wilson AC, Mohr I (2012) A cultured affair: HSV latency and reactivation in neurons. Trends Microbiol 20:604-611. CrossRef Medline

Witko-Sarsat V, Rieu P, Descamps-Latscha B, Lesavre P, HalbwachsMecarelli L (2000) Neutrophils: molecules, functions and pathophysiological aspects. Lab Invest 80:617-653. CrossRef Medline 